\title{
Calpionellid biostratigraphy and microfacies analysis of a Tithonian- Berriasian carbonate succession in the Western Srednogorie (Bulgaria)
}

\author{
Silviya Petroval, Polina Andreeval ${ }^{1}$ Lubomir Metodiev ${ }^{l}$, Daniela Reháková ${ }^{2}$, \\ Jozef Michalik', Iskra Lakova ${ }^{1}$ \\ ${ }^{1}$ Geological Institute, Bulgarian Academy of Sciences, Acad. G. Bonchev Str., Bl. 24, 1113 Sofia, Bulgaria; \\ e-mails: silviya_p@geology.bas.bg,polina_a@geology.bas.bg,lubo@geology.bas.bg,lakova@geology.bas.bg \\ ${ }^{2}$ Comenius University, Faculty of Natural Sciences, Department of Geology and Palaeontology, Mlynská dolina G-229, \\ Ilkovičova 6, SK-84215 Bratislava, Slovak Republic; e-mail: daniela.rehakova@uniba.sk \\ ${ }^{3}$ Slovak Academy of Sciences, Institute of Earth Sciences, Dúbravská 9, P.O. Box 106840 05, Bratislava, Slovak Republic; \\ e-mail:geolmich@savba.sk
}

(Accepted in revised form: July 2017)

\begin{abstract}
In the eastern part of the Western Srednogorie Unit, around Dragovishtitsa Village, a specific succession of the Gintsi and Glozhene-Slivnitsa formations has provided micropalaeontological evidence for late Tithonian (Chitinoidella, Praetintinnopsella and the base of Crassicollaria zones) and mid-Berriasian (the Elliptica Subzone of the Calpionella Zone) age on the basis of 45 chitinoidellid and calpionellid species. A significant stratigraphic hiatus is documented within the Glozhene-Slivnitsa Formation, since a part of the Crassicollaria Zone, as well as the Alpina+Remaniella subzones of the Calpionella Zone, is absent from the Dragovishtitsa 1 section. The conformably overlying Salash Formation is of mid-Berriasian age (Elliptica Subzone) and is locally characterized by the presence of calcareous sandstones (Dragovishtitsa 2 section). The Salash-Cherni Osam Formation, as well as the clayey limestone unit covering the Slivnitsa Formation, is also of mid-Berriasian age (Elliptica Subzone). The Slivnitsa and Glozhene-Slivnitsa formations, which underlie the Salash-Cherni Osam Formation in the Dragovishtitsa East section, correspond to the Crassicollaria Zone and the Alpina Subzone, respectively. Reworking of calpionellids from the Crassicollaria Zone is documented in the Alpina and Elliptica subzones in all three studied sections. Eight microfacies types are distinguished, which suggests that the carbonate sediments were deposited in a carbonate platform rather than in a pelagic basin environment, althought the upper part of the studied sections reveals an upward-deepening trend. The Slivnitsa Formation is covered by highly diachronous sediments from more distal settings: from mid-Berriasian around Dragovishtitsa Village to the Berriasian/Valanginian transition at the Tri Ushi section to late Valanginian in the Dragoman and Kalotina sections. This fact, together with the significant stratigraphic hiatus within the Glozhene-Slivnitsa Formation, is interpreted here as tectonically controlled. The presence of transitional depositional settings from carbonate platform to deeper-marine environments caused deposition of specific lithostratigraphic units not always corresponding to the diagnostic features of the Glozhene, Salash and Cherni Osam formations.
\end{abstract}

Petrova, S., Andreeva, P., Metodiev, L., Reháková, D., Michalík, J., Lakova, I. 2017. Calpionellid biostratigraphy and microfacies analysis of a Tithonian-Berriasian carbonate succession in the Western Srednogorie (Bulgaria). Geologica Balcanica 46 (1), 65-92.

Keywords: Tithonian, Berriasian, microfacies analysis, stratigraphy, calpionellids, Western Srednogorie, Bulgaria.

\section{INTRODUCTION}

The Western Srednogorie Unit is a part of the Srednogorie Zone, which belongs to the Alpine orogen. The Upper Jurassic-Lower Cretaceous deposits are poorly studied in its eastern part (Sapunov et al., 1985; Sapunov and Tchoumatchenco, 1995; Nikolov, 1995), un- like the western one, where a number of studies have been conducted over the last 50 years (Mandov, 1967, 1970, 1976; Nikolov and Tzankov, 1998; Ivanova et al., 2000, 2008; Mandov and Nikolov, 2001; Ivanova and Koleva-Rekalova, 2004; Petrova et al., 2010, 2011). During the last geological mapping of the area in scale 1:50 000, it became evident that the Upper 
Jurassic-Lower Cretaceous successions do not correspond to the conventional lithostratigraphic scheme that is currently in use. Apart from the data presented by Sapunov et al. (1985), no other biostratigraphic evidence has been published so far and the overall succession has remained without precise age assessment. Moreover, at many levels, these rocks need to be addressed in more details in terms of their lithology.

The eastern part of the Western Srednogorie attracted the interest of the present authors for the following reasons: 1) occurrence of unique carbonate development with pelagic microfossils (calpionellids); 2) lack of previous study on carbonate microfacies; 3) scarcity of palaeontological data for age determination of strata younger than Kimmeridgian; 4) new results gained during the last geological mapping of the area in scale 1:50 000.

This paper presents description of Tithonian and Berriasian carbonate sections in the Western Srednogorie, north of Dragovishtitsa Village (Fig. 1 $a-c$ ), including calpionellid distribution and precise dating, regional stratigraphical implications, microfacies analysis and basin development inference for the end of the Jurassic and beginning of the Cretaceous in the study region.

Contributions to this study are as follows: Silviya Petrova (calpionellid taxonomy and biostratigraphy); Daniela Reháková (calpionellid biostratigraphy and foraminifera identification); Polina Andreeva and Jozef Michalík (microfacies analysis and basin development); Lubomir Metodiev (lithostratigraphy, regional geology and geological mapping), and Iskra Lakova (regional stratigraphy).

\section{GEOLOGICAL SETTING}

The Upper Jurassic and Lower Cretaceous carbonate rocks in the Western Srednogorie tectonic unit are mainly represented by the massive biogenic limestones of the Slivnitsa Formation deposited under conditions of a long-lived carbonate platform. These are of Callovian to Valanginian age (Ivanova, 1999; Ivanova and Koleva-Rekalova, 2004). In the westernmost part of this tectonic unit (in Dragoman area), the Slivnitsa Formation is unconformably covered by the hemipelagic limestones and marlstones of the Salash Formation of Valanginian and Hauterivian age (Mandov, 1967, 1970, 1976; Nikolov and Tzankov, 1998; Ivanova et al., 2000, 2008; Mandov and Nikolov, 2001; Petrova et al., 2010). Eastwards, this development rapidly becomes different, including poorly defined successions of platform, pelagic and hemipelagic carbonates, commonly containing intermediate lithologies in which both allochthonous and autochthonous components occur. It is only in the eastern part of the Western Srednogorie Unit that the "pelagic" Upper Jurassic and Lower Cretaceous formations have been described (Sapunov et al., 1985).
Three sections were studied: Dragovishtitsa $1 \mathrm{sec}-$ tion (GPS: 42 $\left.51^{\prime} 45^{\prime \prime} \mathrm{N} ; 2^{\circ} 13^{\prime} 30^{\prime \prime} \mathrm{E}\right)$; Dragovishtitsa 2 section (GPS: 42 $51^{\prime} 45^{\prime \prime} \mathrm{N} ; 2^{\circ} 13^{\prime} 31^{\prime \prime} \mathrm{E}$ ) and Dragovishtitsa East section (see Fig. 1a) situated NNE of Dragovishtitsa Village (Sofia District). The former two sections are located on the southeastern slope of the Mezhdina Summit and represent a natural extension of one another but with a quite different lithology. Section Dragovishtitsa East is a previously sampled section that actually is located on the territory of the active Balsha Quarry. The subject of this study are the Gintsi and Glozhene-Slivnitsa formations in the Dragovishtitsa 1 section, the Glozhene-Slivnitsa and the Salash formations in the Dragovishtitsa 2 section, as well as the Slivnitsa, Glozhene-Slivnitsa and the rhythmic alternation attributed to the Salash-Cherni Osam Formation in the Dragovishtitsa East section (Fig. 1b,c).

\section{MATERIAL AND METHODS}

A total of 59 thin-sections (15 from the Dragovishtitsa 1 section, 28 from the Dragovishtitsa 2 section, 14 from the Dragovishtitsa East section and two from the clayey limestone unit at the top of the Mezhdina Summit) were studied for chitinoidellids and calpionellids with a Jenaval transmitting light-microscope. Microfacies analysis is based on detailed microscopic study of 52 thin-sections (15 from the Dragovishtitsa 1 section, 23 from the Dragovishtitsa 2 section, and 14 from the Dragovishtitsa East section), viewed on a standard petrographic microscope. The Dragovishtitsa East section was sampled in 1995 by I. Lakova. Sampling density in all three sections depends on exposure. The average sampling density is one sample/metre. Samples for thin-sections were taken preferentially from limestones. Microfacies types have been identified, following the textural classification proposed by Dunham (1962) and the diagnostic microfacies criteria of Flügel (2004). The field observations, calpionellid biostratigraphy and depositional setting interpretations were made jointly with Daniela Reháková and Jozef Michalík. The interpretation of resedimented chitinoidellid and calpionellid species was based on their occurrence in younger strata and/or in transported intraclasts. The examined materials are hosted at the Geological Institute of the Bulgarian Academy of Sciences (Sofia).

\section{LITHOSTRATIGRAPHY}

The work of Sapunov et al. (1985) on the lithostratigraphy, biostratigraphy and regional distribution of the Upper Jurassic carbonate rocks in the area north of Dragovishtitsa Village was the first and still is the most comprehensive study. Those authors described two sections on the southern slope of the Mezhdina Summit. The lithostratigraphic succession recognized from base to top was as follows: Polaten, Yavorets, 

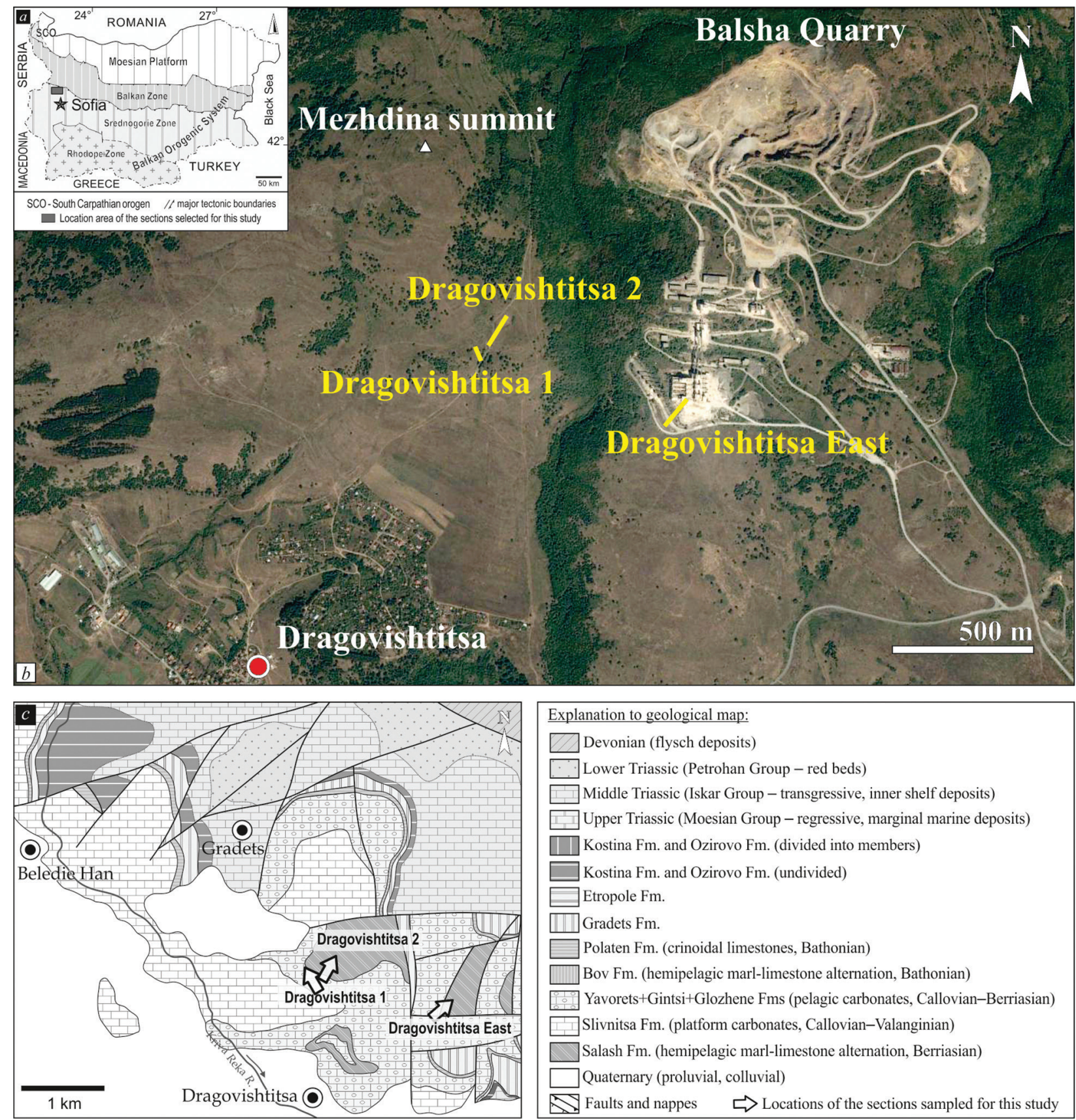

Fig. 1. Location of the studied sections: $a$ ) Tectonic subdivision of Bulgaria (Dabovski and Zagorchev, 2009; modified); $b$ ) Geographic position of the sections (the map is a satellite image provided by Google Earth); c) Geological map of the studied area and position of the sections.

Gintsi, Glozhene, Slivnitsa and Salash formations. Calpionellid data by D. Bakalova (in: Sapunov et al., 1985) suggested the presence of the Alpina and Elliptica subzones in the Salash Formation. On the northern slope of Mezhdina Summit, Sapunov et al. (1985) described a succession consisting of the Polaten, Slivnitsa and Salash formations. The authors pointed out the unique nature of the Dragovishtitsa area, where sediments of various depositional settings are in close proximity to each other. The geological mapping of the area in scale 1:100 000 revealed the presence of another lithostratigraphic unit, the Salash-Cherni Osam Formation (Nikolov, 1995), as well as a direct contact between the Slivnitsa and Salash formations (Sapunov and Tchoumatchenco, 1995). Recent geological mapping of the area in scale 1:50 000 has contributed with additional information on the lithostratigraphy, distribution and relationships between the formations 
(see Fig. 1c). A small, isolated and strongly tectonized outcrop south of Dragovishtitsa Village was assigned to the Salash-Cherni Osam Formation.

In the herein studied eastern part of the Western Srednogorie Unit, the Polaten Formation underlies all carbonate Callovian and Upper Jurassic rocks. Starting from the Callovian-Oxfordian, the sediments of the Polaten Formation (mainly grey allochemic sandy limestones of Bathonian age) are unconformably covered by formations of two differentiated facies types: the carbonate-platform massive biogenic limestones of the Slivnitsa Formation to the north and to the west, and the "pelagic" limestones of the West Balkan Carbonate Group (Yavorets+Gintsi+Glozhene formations, see Nikolov and Sapunov, 1970) to the southsoutheast. The Glozhene Formation is covered by an alternation of clayey limestones and calcareous sandstones. This alternation was described and referred to the Salash Formation by Sapunov et al. (1985). The occurrence of sandstones, which increase in abundance upwards, is, however, quite atypical of the Salash Formation (Nikolov and Zankov, 1971). Therefore, this alternation should be regarded in different manner, from lithostratigraphic point of view. Two solutions seem possible: to retain it as the Salash Formation, but paying attention to the sandstone component, or to attribute it to the Salash-Cherni Osam Formation of Nikolov (1995). The latter bears resemblance to both the Salash and the Cherni Osam formations by having an intermediate hemipelagic-turbidity character of the sediments. Recent field observations across the area containing the sections of this study did not reveal the presence of turbidity deposits. The appearance of sandstones in our sections does not seem sufficient to attribute these intervals to the Salash-Cherni Osam Formation. On the other hand, the former studies of the area have shown that a mixed hemipelagic-turbidity development really existed, but now it cannot be confirmed, as outcrops have disappeared due to the active expansion of the Balsha Quarry. The only outcrop that resembles the lithology of the Salash-Cherni Osam Formation is that to the south of Dragovishtitsa Village, but it is so deformed that it is impossible to restore the original stratification of the rocks. Therefore, the name Salash-Cherni Osam Formation is used in this study conditionally.

\section{Yavorets Formation}

This unit covers unconformably the Polaten Formation. The boundary between the two formations is sharp, associated with submarine break in sedimentation (Sapunov et al., 1985). The Yavorets Formation consists of hard, grey, medium-bedded micritic limestones, with an approximate total thickness of $20 \mathrm{~m}$ to $40 \mathrm{~m}$. It was considered as middle Callovian to early late Oxfordian in age by Sapunov et al. (1985). Micropalaeontological evidence from calcareous dinocysts and foraminifera determined by D. Ivanova (in: Petro- va et al., 2014), indicated that the exposures of the Yavorets Formation to the southeast of Dragovishtitsa Village are of middle Callovian to Oxfordian age.

\section{Gintsi Formation}

The unit consists of grey to pinkish-grey, mediumbedded nodular limestones. The measured thickness is $26 \mathrm{~m}$. The age determined based on ammonites (Sapunov et al. 1985) is late Oxfordian to early Kimmeridgian. The uppermost part of the Dragovishtitsa 1 section is proven herein to be of earliest late Tithonian age, based on calpionellids (the Boneti Subzone of the Chitinoidella Zone).

\section{Slivnitsa Formation}

In its typical development, this unit crops out largely in the south and west parts of the area around Dragovishtitsa Village. The Slivnitsa Formation is composed of light grey, thick-bedded to massive, intraclastic and bioclastic limestones. It covers with short lithological transition the Glozhene Formation. The age of the Slivnitsa Formation is coeval with the upper parts of the Gintsi Formation and the Glozhene Formation, and locally these formations may interfinger. Sapunov et al. (1985) considered it as late Tithonian to early Berriasian in age. The age indicated by calpionellids in the Dragovishtitsa East section is late Tithonian (Crassicollaria Zone, Massutiniana Subzone).

\section{Glozhene-Slivnitsa Formation}

The bulk of exposures in the Dragovishtitsa area show lithological features similar to the Glozhene Formation, but they differ in lithology from the typical pelagic deposits in the Western Balkan region. Commonly, the grey micritic limestones are medium- to thick-bedded, intraclastic to bioclastic, with chert nodules or platty chert interlayers. In some cases, it is difficult to attribute these rocks to either the Glozhene or the Slivnitsa Formation. The microfossil content includes pelagic elements (chitinoidellids, calpionellids, calcareous dinocysts, saccocomids, globochaetids as basic constituents), which are mixed with bryozoans, foraminifera, calcareous green algae, LithocodiumBacinella, pelecypods, gastropods and coral fragments of shallow-water depositional settings. Regarding both the field appearance and spatial relationships with the underlying Gintsi Formation and the short lateral transitions to the typical Slivnitsa Formation, we assign this part of the carbonate succession to the GlozheneSlivnitsa Formation. It corresponds to parts of the upper Tithonian and the lower Berriasian. Noteworthy is a newly discovered stratigraphic hiatus covering the Tithonian-Berriasian boundary interval (i.e., the absence of the greatest part of the Crassicollaria Zone and Alpina+Remaniella subzones of the Calpionella Zone) in the Dragovishtitsa 1 section. Early Berriasian 
age (the Alpina Subzone of the Calpionella Zone), is established for the formation in the Dragovishtitsa East section.

\section{Salash Formation}

This unit represents an irregular alternation of thinbedded, grey, clayey limestones, marlstones and rare siltstones, with thin interbeds of yellowish calcareous sandstones. The sandstones increase in abundance upsection. The measured thickness is $26 \mathrm{~m}$. The age is determined here as late early Berriasian (the Elliptica Subzone of the Calpionella Zone).

\section{Clayey limestone unit}

Sapunov et al. (1985) considered the Salash Formation to be a lithostratigraphic unit of dark grey, mediumbedded, micritic, clayey and intraclastic limestones that cover directly the Slivnitsa Formation. However, this succession lacks the diagnostic features of the Salash Formation, i.e., alternation of micritic and clayey limestones or of clayey limestones and marlstones (Nikolov and Zankov, 1971). It differs from the Salash Formations at the Dragovishtitsa 2 section, too. For these reasons, we designate it informally as clayey limestone unit. The age indicated by calpionellids is latest early Berriasian (the Elliptica Subzone of the Calpionella Zone).

\section{Salash-Cherni Osam Formation}

Nikolov (1995) used this formal name for a threecomponent alternation of sandstones, marlstones and clayey to micritic limestones that overlie the Glozhene Formation and are laterally replaced to the north-west by the Salash Formation. The Salash-Cherni Osam Formation corresponds to the uppermost lower Berriasian, as documented here (the Elliptica Subzone of the Calpionella Zone) in the Dragovishtitsa East section.

\section{BIOSTRATIGRAPHY}

Calpionellid zones and subzones follow the definitions and zonal schemes of Pop (1997a), Reháková and Michalík (1997) and Lakova and Petrova (2013). The Tithonian Chitinoidella and Praetintinnopsella zones, along with the base of the Crassicollaria (Remanei Subzone), and the lower Berriasian Elliptica Subzone of the Calpionella Zone have been documented in Dragovishtitsa 1 section. It is noteworthy that a large portion of the uppermost Tithonian Crassicollaria Zone (almost the entire Remanei Subzone, without its base, and the Massutiniana Subzone) and the lower Berriasian Alpina and Remaniella subzones of the Calpionella Zone are absent in this section. The Elliptica Subzone has been recorded in the Dragovishtitsa 2 section and in Dragovishtitsa East section, in the latter section together with the Crassicollaria Zone (upper parts of the Massutiniana Subzone) and the Alpina Subzone of the Calpionella Zone. Previous record of the chitinoidellids in other parts of the Alpine-Carpathian region has been taken into account, e.g., in the Carpathians of Slovakia (Borza, 1969; Reháková, 2000), and Romania (Pop, 1997b), as well as in more distant areas, such as Tunisia (Sallouhi et al., 2011) and Argentina (Kietzmann, 2017).

\section{Dragovishtitsa 1 section}

This section includes the Gintsi and Glozhene-Slivnitsa formations. Vertical distribution of the chitinoidellid and calpionellid species is shown in Fig. 2, and chitinoidellids are documented in Figs 3 and 4.

The Chitinoidella Zone (samples K 01-K 06a, see Fig. 2) corresponds to the upper part of the Gintsi Formation $(10 \mathrm{~m})$ and the basal $3 \mathrm{~m}$ of the GlozheneSlivnitsa Formation. The Dobeni Subzone (pars.) has been recorded in the Gintsi Formation (sample K 01). The association is scarce and consists of only four species: Longicollaria dobeni, Borziella slovenica, Daciella banatica and Dobeniella colomi. The Boneti Subzone (samples K 02-K 06a) covers the top of the Gintsi Formation and the base of the Glozhene-Slivnitsa Formation, being 5-6 m thick. The chitinoidellid association is diverse. Characteristic representatives of the Dobeni Subzone (e.g., Daciella almajica, Daciella danubica, Daciella svinitensis and Dobeniella tithoni$\mathrm{ca}$ ) occur, along with species typical for the Boneti Subzone: Dobeniella bermudezi, Dobeniella cubensis, Longicollaria insueta, Chitinoidella sp. and Popiella oblongata. The first occurrence (FO) of Almajiella cristobalensis, Carpathella rumanica and Chitinoidella elongata is marked in the top of the subzone. Preservation is moderate to poor, and it is not rare for some species to occur only as single specimens.

According to the recent chronostratigraphic scale of the Tithonian (Ogg and Hinnov, 2012), the upper Tithonian includes the Microcanthoceras microcanthum and Durangites ammonite zones. Direct correlations of ammonites and calpionellids have shown that the base of the Boneti Subzone coincides precisely with the base of the Microcanthoceras microcanthum Zone in Spain, France, Morocco and Tunisia (Enay and Geyssant, 1975; Cecca et al., 1989; Boughdiri et al., 2009; Benzaggagh et al., 2010). Thus, the base of the Boneti Subzone is a reliable indicator for the base of the upper Tithonian.

The Praetintinnopsella Zone (1.5 m thick, samples $\mathrm{K} 06 \mathrm{~b}-\mathrm{K} 06 \mathrm{c}$ ) is represented by its index-species accompanied with certain chitinoidellid species from the Dobeni and Boneti subzones in the mid of the Glozhene-Slivnitsa Formation (see Fig. 2). Dobeniella pinarensis, Chitinoidella carthagensis, Chitinoidella hegarati and Chitinoidella popi were also recorded. The last occurrences (LOs) of Dobeniella bermudezi and Dobeniella cubensis were recorded at the top of the zone. 


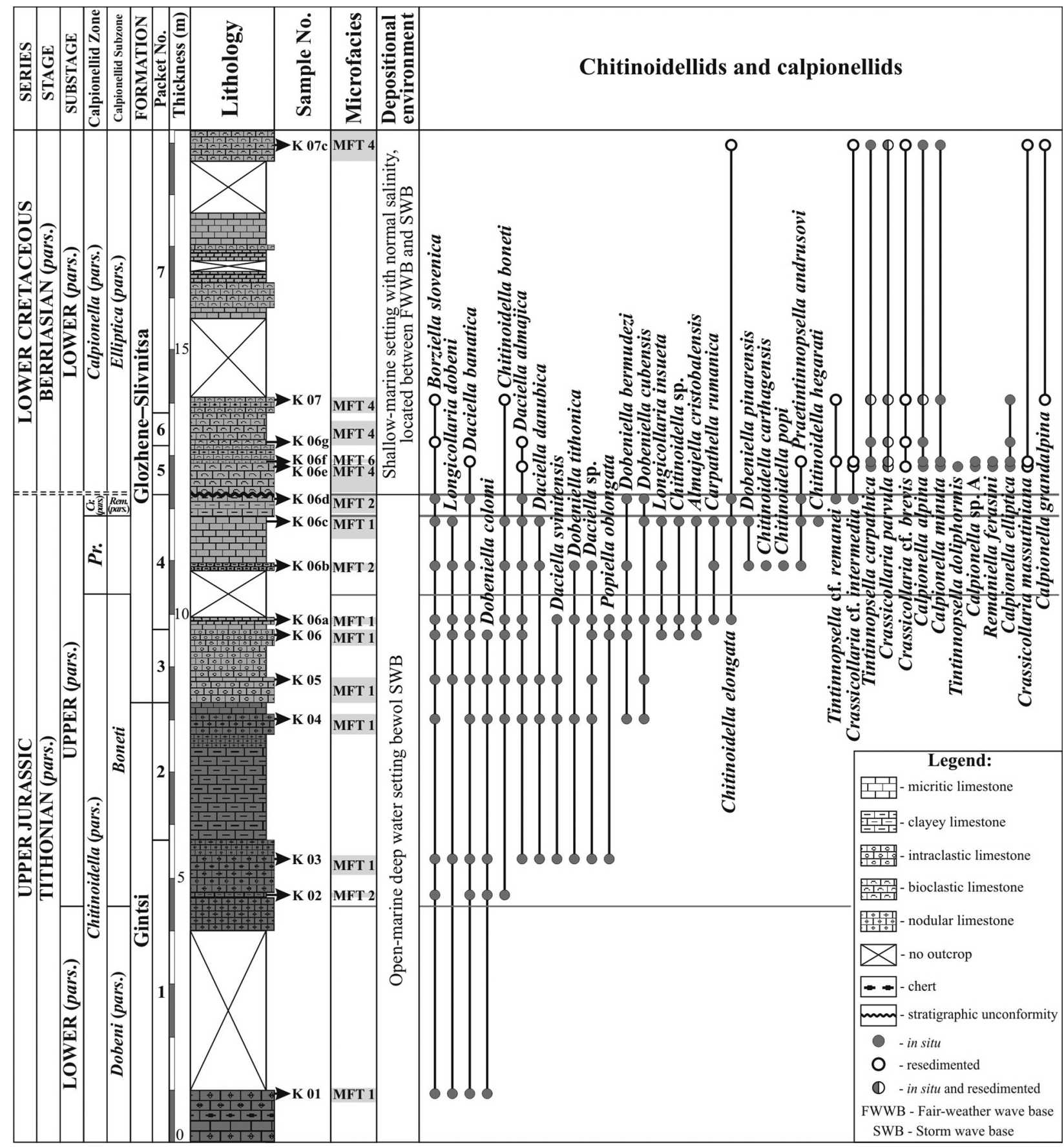

Fig. 2. Dragovishtitsa 1 section - litho- and biostratigraphy, range-chart of the calpionellid species, microfacies types and interpretation of the depositional environment.

Fig. 3. Chitinoidellids of the Dragovishtitsa 1 section: 1-3) Longicollaria dobeni, sample K 05 (1), sample K 06 (2), sample K 06a (3); 4, 5) Borziella slovenica, sample K 03 (4), sample K 06a (5); 6-8) Daciella almajica, sample K 03 (6), sample K 04 (7), sample K 06b (8); 9, 10) Daciella banatica, sample K 03 (9), sample K 05 (10); 11, 12) Daciella danubica, sample K 04 (11), sample K 06c (12); 13-15) Daciella svinitensis, sample K 03 (13), sample K 04 (14), sample K 06a (15); 16, 17) Dobeniella colomi, sample K 04 (16), sample K 06 (17); 18, 19) Dobeniella tithonica, sample K 04 (18), sample K 06a (19); 20, 21) Carpathella rumanica, sample K 06b (20), sample K 06c (21); 22-24) Chitinoidella boneti, sample K 06a (22, 23), sample K 06b (24); 25, 26) Chitinoidella elongata, sample K 06a (25), sample K 06c (26); 27, 28) Popiella oblongata, sample K 06 (27), sample K 06a (28); 29, 30) Daciella sp., sample K 04 (29), sample K 06a (30). 

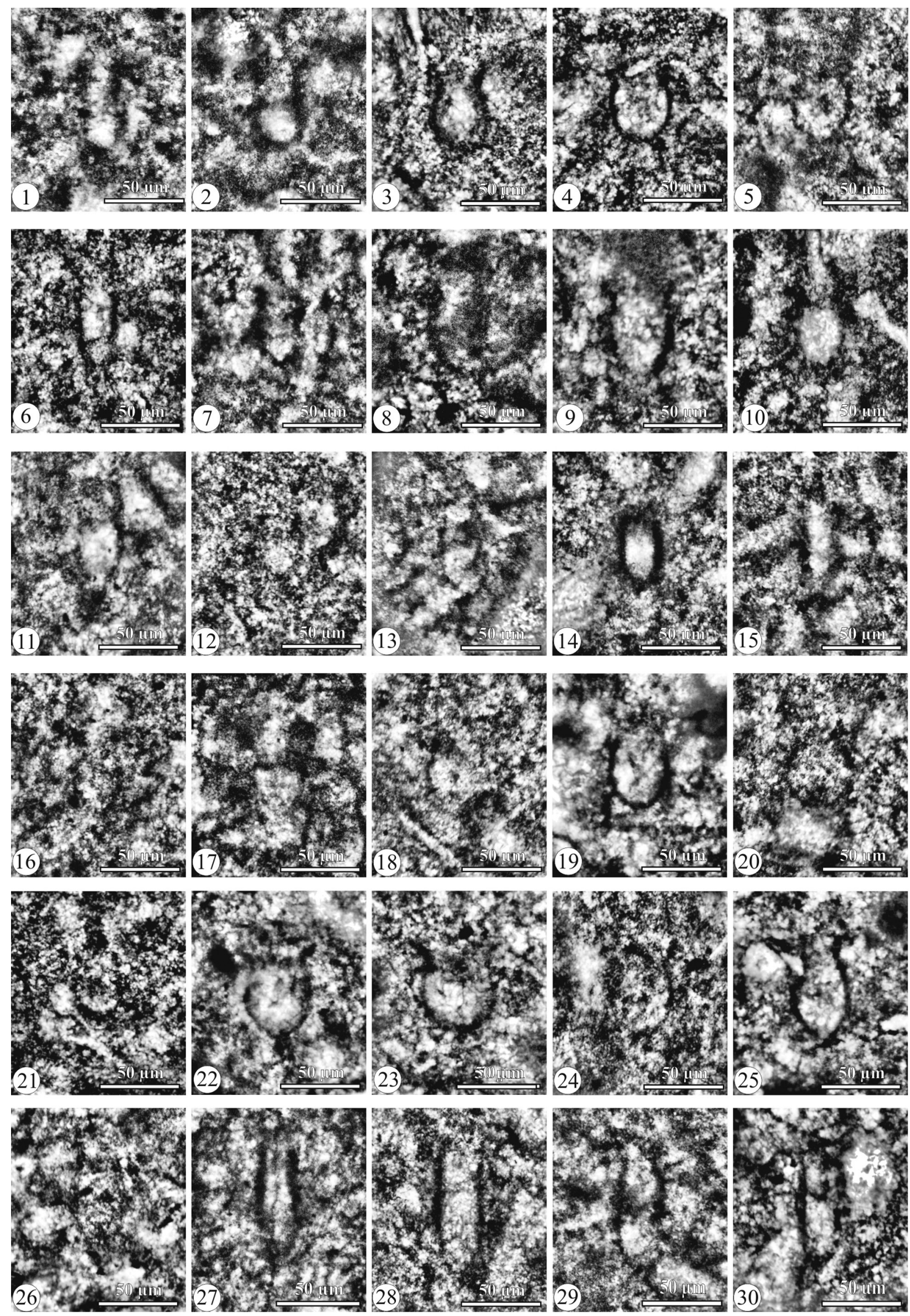
The Crassicollaria Zone (Remanei Subzone) is indicated in one sample only (K 06d, see Fig. 2). The assemblage is characterized by the presence of the index-species of the Remanei Subzone, Tintinnopsella cf. remanei, as well as Crassicollaria cf. intermedia, Praetintinnopsella andrusovi and some representatives of chitinoidellids.

The Calpionella Zone (Elliptica Subzone) corresponds to a $\sim 7 \mathrm{~m}$ thick interval of the top of the Glozhene-Slivnitsa Formation at the Dragovishtitsa
1 section (samples K 06e-K 07c, see Fig. 2). The calpionellid assemblage includes Calpionella alpina, Calpionella minuta, Calpionella elliptica, Calpionella sp. A (transitional form between Calpionella alpina and Calpionella elliptica), Tintinnopsella carpathica, Tintinnopsella doliphormis, Crassicollaria parvula, Remaniella ferasini. Apart from the calpionellids, abundant fragments of bryozoans, benthic foraminifera, green calcareous algae and Lithocodium-Bacinella that are characteristic of the shallow-marine settings
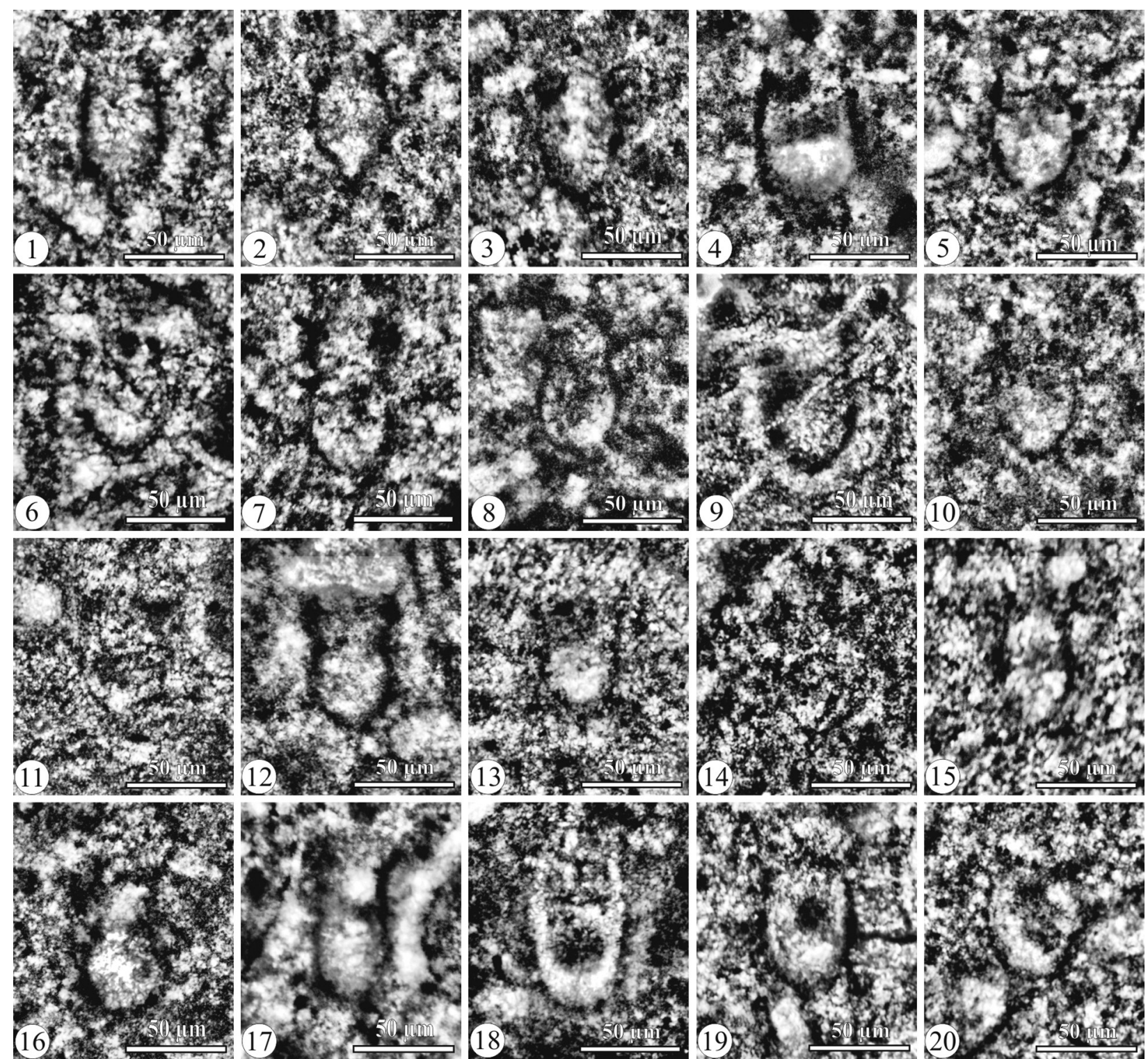
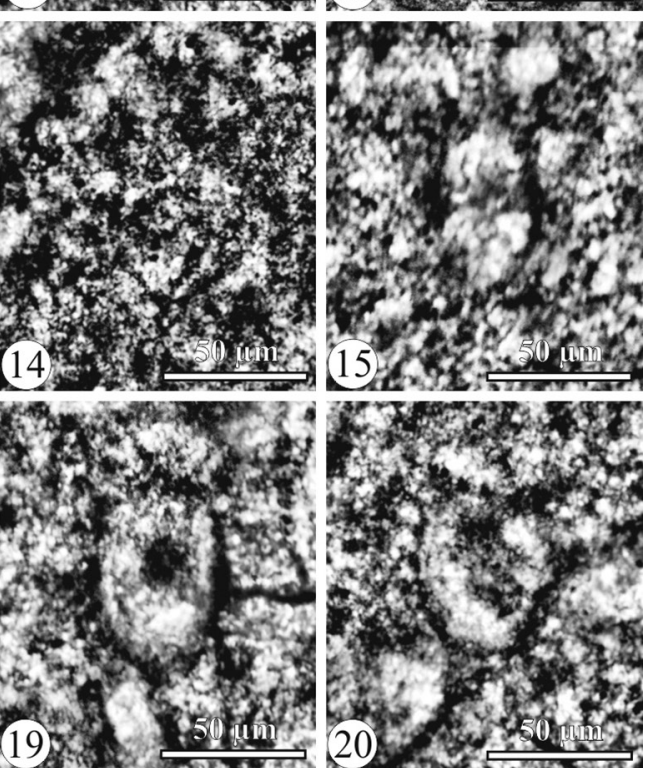

Fig. 4. Chitinoidellids and semichitinoidellids of the Dragovishtitsa 1 section: 1, 2) Chitinoidella sp., sample K 06a (1), sample K 06c (2); 3) Chitinoidella carthagensis, sample K 06b; 4) Chitinoidella popi, sample K 06b; 5, 6) Chitinoidella hegarati, sample K 06c; 7-9) Dobeniella bermudezi, sample K 04 (7), sample K 06 (8), sample K 06b (9); 10, 11) Dobeniella cubensis, sample K 04 (10), sample K 06d (11); 12, 13) Almajella cristobalensis, sample K 06 (12), sample K 06c (13); 14, 15) Dobeniella pinarensis, sample K 06b (14), sample K 06c (15); 16, 17) Longicollaria insueta, sample K 06 (16), sample K 06a (17); 18-20) Praetintinnopsella andrusovi, sample K 06b (18), sample K 06c $(19,20)$. 


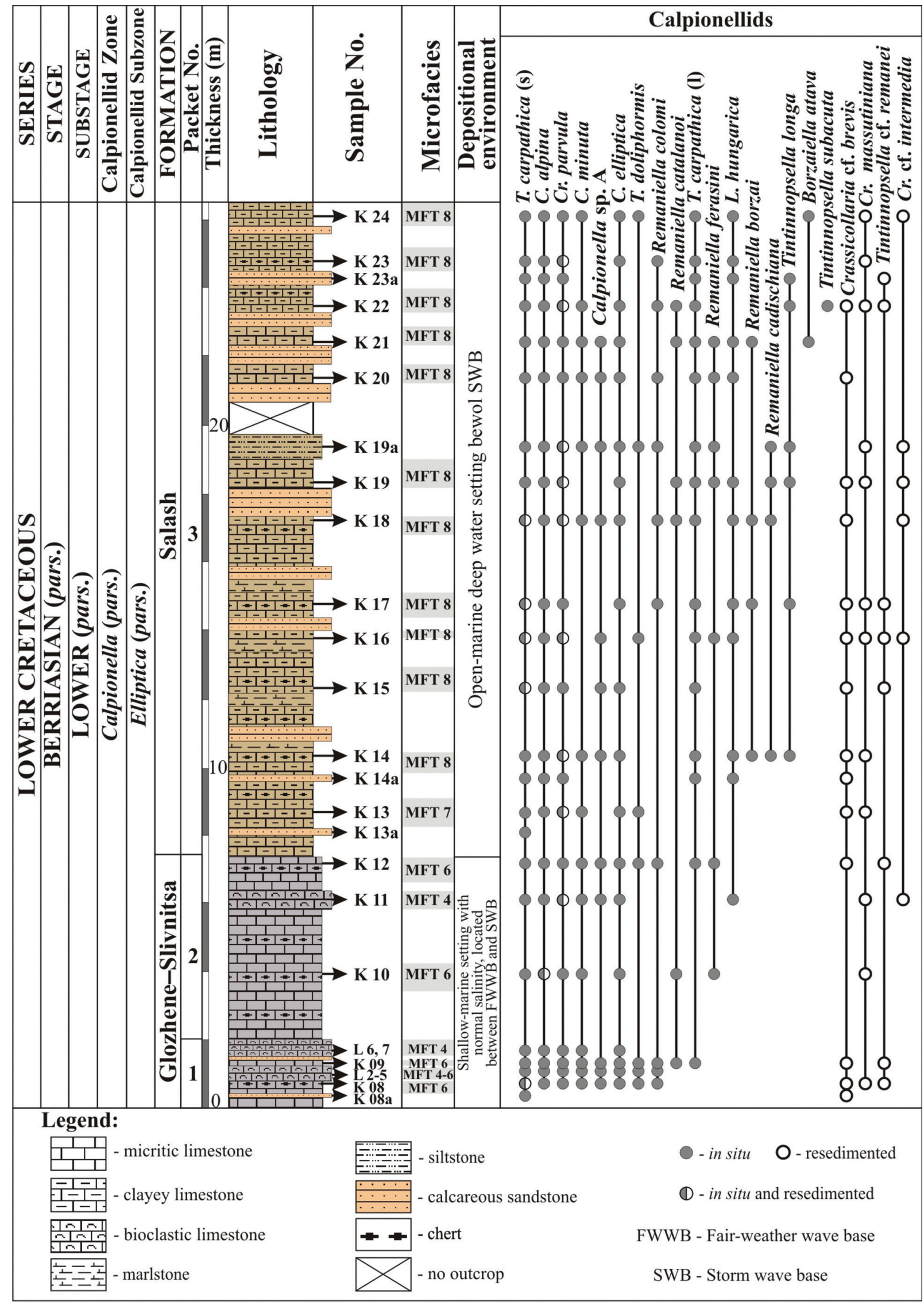

Fig. 5. Dragovishtitsa 2 section - litho- and biostratigraphy, range-chart of the calpionellid species, microfacies types and interpretation of the depositional environment. 
occur. Resedimented calpionellids were recorded in the Elliptica Subzone at the Dragovishtitsa $1 \mathrm{sec}-$ tion, such as Borziella slovenica, Daciella banatica, Daciella almajica, Chitinoidella boneti and Chitinoidella elongata from the Chitinoidella Zone, as well as Crassicollaria cf. brevis, Crassicollaria massutiniana, Crassicollaria cf. intermedia, Tintinnopsella cf. remanei and Calpionella grandalpina. The latter forms are from the missing part of the Crassicollaria Zone and suggest a post-depositional washout of adjacent older strata.

The stratigraphic hiatus recorded here corresponds to part of the upper Tithonian (the greatest part of Crassicollaria Zone) and the lower Berriasian (Alpina and Remaniella subzones of the Calpionella Zone). This result is somewhat surprising, as in all pelagic sections previously studied in the West Balkan and West Fore-Balkan in Bulgaria (Lakova et al., 1999; Lakova and Petrova, 2013) there is a complete record of sedimentation across the Tithonian/Berriasian boundary. Here, the considerable hiatus reflects most probably dynamic conditions on the shelf where sediments had been destroyed and reworked. This is evidenced by the resedimentation of chitinoidellids and crassicollarians in younger strata. Similar palaeoenvironmental conditions were described by Michalík et al. (2012) from the Manín Unit of the Western Carpathians.

\section{Dragovishtitsa 2 section}

The Glozhene-Slivnitsa Formation (7.5 m thick) and the Salash Formation (19 m thick) crop out in this section. Vertical distribution of the calpionellid species is shown in Fig. 5, and the calpionellids themselves are illustrated in Fig. 6.

Starting with the top of the Glozhene-Slivnitsa Formation, the whole section corresponds to the Elliptica Subzone of the Calpionella Zone. The calpionellid assemblage is quite rich in species (see Figs 5, 6). The occurrence of Remaniella cadischiana, Tintinnopsella subacuta, Borzaiella atava and Tintinnopsella longa suggests that the upper $17 \mathrm{~m}$ of the section belong to the uppermost Elliptica Subzone. Similar calpionellid succession has recently been reported from the
Barlya section (Grabowski et al., 2016), where in the mid-Elliptica Subzone Remaniella borzai, Lorenziella hungarica have their FOs and the large variety of Tintinnopsella carpathica becomes abundant. Additional members of the assemblage are Calpionella alpina, Calpionella minuta, Calpionella sp. A, Crassicollaria parvula, Tintinnopsella doliphormis, and more common species of the genus Remaniella, such as Remaniella catalanoi, Remaniella ferasini and Remaniella colomi. Interestingly, the diversity and the abundance of calpionellids in this section did not differ from pelagic environments. As a whole, calpionellids show greater diversity and abundance in the Western Balkan Unit and the Western Srednogorie Unit compared to those in the Western Carpathians in Slovakia (D. Reháková, unpublished data). Resedimented species from the Crassicollaria Zone were observed again. These are Crassicollaria cf. brevis, Crassicollaria massutiniana, Crassicollaria cf. intermedia and Tintinnopsella $\mathrm{cf}$. remanei.

\section{Dragovishtitsa East section}

This section is located in the active Balsha Quarry (Fig. 1b). Above the bioclastic limestones of the Slivnitsa (6 $\mathrm{m}$ thick) and then of the GlozheneSlivnitsa Formation ( $4 \mathrm{~m}$ thick), a triple alternation of calcareous sandstones, marlstones and clayey to micritic limestones occur (Salash-Cherni Osam Formation, $16 \mathrm{~m}$ thick) (Fig. 7). This section was mentioned by Nikolov (1995). The three formations here studied are separated by unexposed intervals. The vertical distribution of calpionellid species recorded in this section is shown in Fig. 7. The calpionellids are presented in Fig. 8. The Slivnitsa Formation is dated as late Tithonian (the Massutiniana Subzone of the Crassicollaria Zone, samples 401-405), and the Glozhene-Slivnitsa Formation as earliest Berriasian (the Alpina Subzone of the Calpionella Zone, samples 406-407). The rhythmic alternation of sandstones, marlstones and clayey/micritic limestones of the Salash-Cherni Osam Formation corresponds to the mid-Berriasain Elliptica Subzone of the Calpionella Zone (samples 408-414).

Fig. 6. Calpionellids of the Dragovishtitsa 2 section: 1-3) Calpionella alpina, sample K 09 (1, 2), sample K 19a (3); 4, 5) Calpionella sp. A (transitional form between Calpionella alpina and Calpionella elliptica), sample K 08 (4), sample K 20 (5); 6, 7) Calpionella elliptica, sample L 4 (6), sample K 23 (7); 8, 9) Calpionella minuta, sample K 19a (8), sample K 24 (9); 10, 11) Crassicollaria parvula, sample K 12 (10), sample K 19a (11); 12, 13) Lorenziella hungarica, sample K 18 (12), sample K 23 (13); 14, 15) Tintinnopsella carpathica (small forms), sample K 15 (14), sample K 24 (15); 16, 17) Tintinnopsella carpathica (large forms), sample K 15; 18, 19) Tintinnopsella doliphormis, sample K 19a (18), sample K 24 (19); 20, 21) Tintinnopsella subacuta, sample K 22; 22, 23) Tintinnopsella longa, sample K 22 (22), sample K 17 (23); 24, 25) Remaniella cadischiana, sample K 19 (24), sample K 18 (25); 26) Remaniella catalanoi, sample K 19; 27) Remaniella borzai, sample K 14; 28) Remaniella colomi, sample K 08; 29) Remaniella ferasini, sample K 21;30) Borzaiella atava, sample 24. 

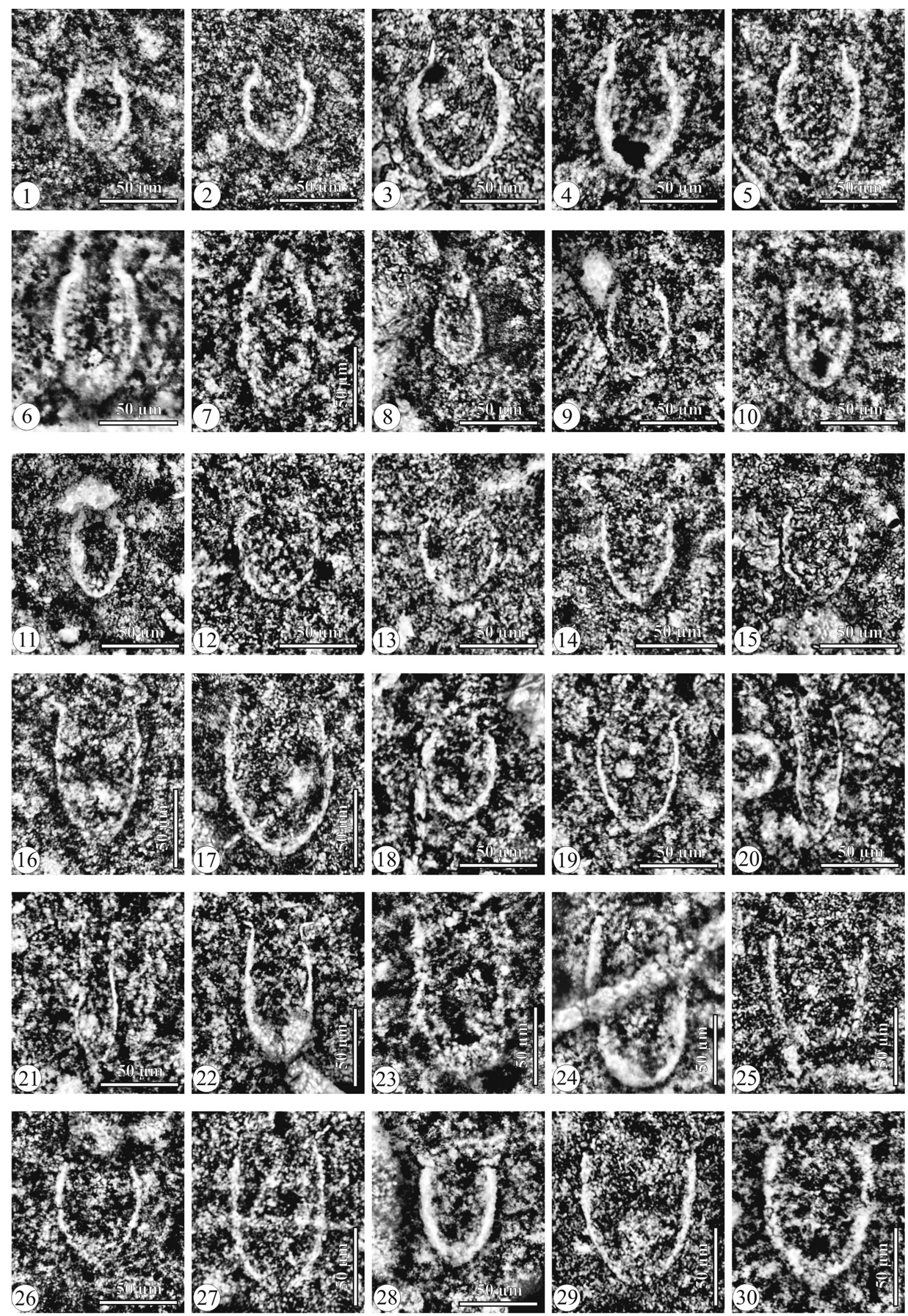
The Crassicollaria Zone in this section is represented by its upper subzone, the Massutiniana Subzone. The calpionellids are rare and poorly preserved, and some of them are resedimented. The as- semblage of the subzone includes Crassicollaria cf. brevis, Crassicollaria cf. intermedia, Crassicollaria massutiniana, Crassicollaria parvula, Tintinnopsella carpathica, Calpionella alpina, Calpionella grandal-

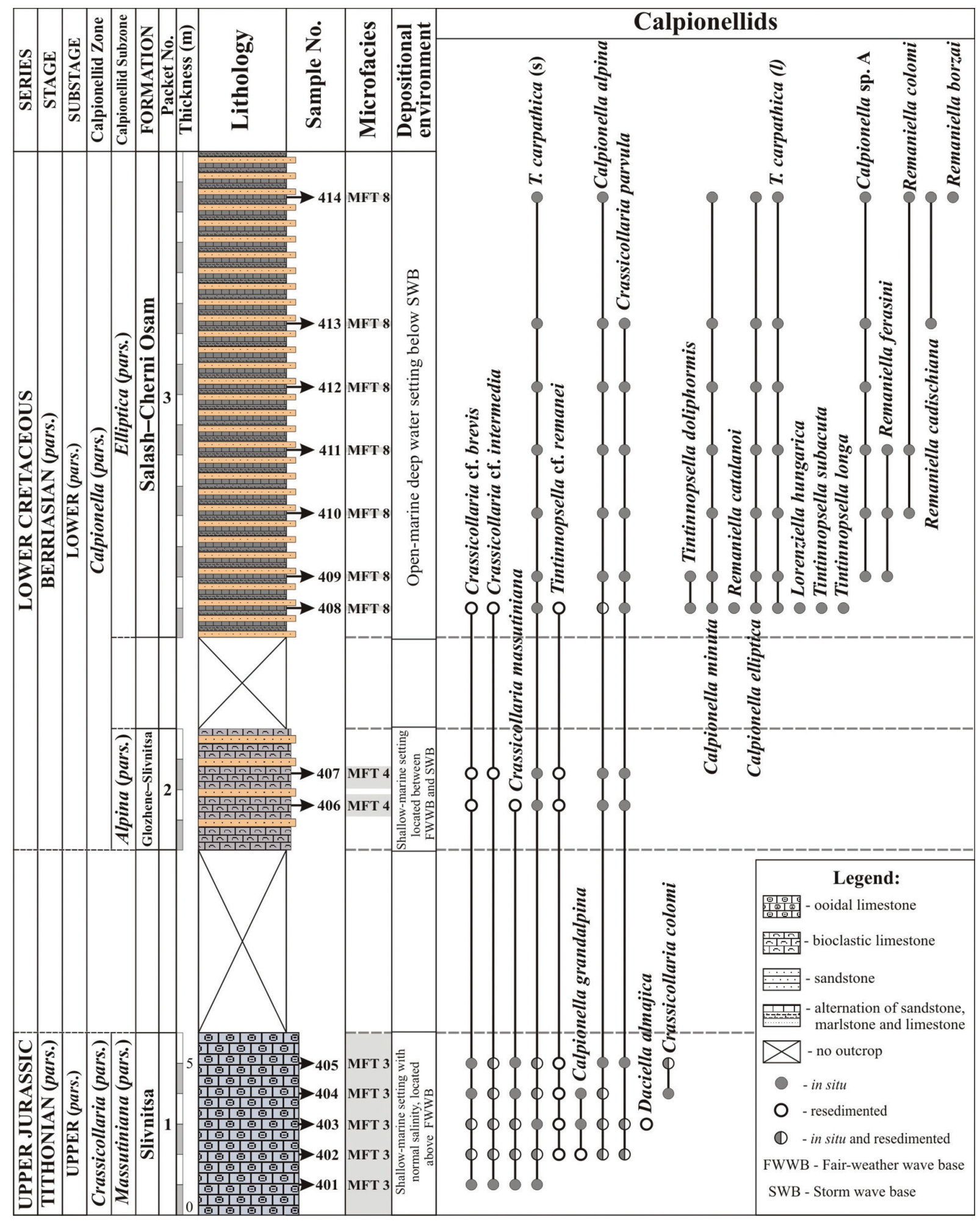

Fig. 7. Dragovishtitsa East section - litho- and biostratigraphy, range-chart of the calpionellid species, microfacies types and interpretation of the depositional environment. 
pina and Crassicollaria colomi, also resedimented Tintinnopsella cf. remanei and Daciella almajica. The presence of Crassicollaria colomi indicates the upper parts of the subzone.

The Calpionella Zone is represented by two of its three subzones: Alpina and Elliptica. The Alpina Subzone is characterized by the presence of Calpionella alpina, Crassicollaria parvula and Tintinnopsella carpathica. The assemblage also includes resedimented representatives of Crassicollaria cf. brevis, Crassicollaria cf. intermedia, Crassicollaria massutiniana and Tintinnopsella cf. remanei. All calpionellids in this subzone are poorly preserved. The absence of diagnostic species, such as Crassicollaria colomi, Tintinnopsella doliphormis and Calpionella minuta, suggests that these are middle parts of the Alpina Subzone. The Elliptica Subzone has almost the same assemblage as the one noted in the Dragovishtitsa 2 section. The whole interval, between samples 408 and 414, seems to represent the top of the Elliptica Subzone since Tintinnopsella longa and Tintinnopsella subacuta occur in sample 408 (see Fig. 7).

\section{Clayey limestone unit at the Mezhdina Summit}

Both the Slivnitsa Formation to the northwest and the Salash Formation in the Dragovishtitsa 2 section are covered by a largely cropping out lithological body consisting of dark grey medium-bedded clayey and intraclastic limestones. Our interest in its micropalaeontological content and age has been provoked by the chance to elucidate the problem of westward rejuvenation of the top of the Slivnitsa Formation and its immediate cover and the timing of drowning of the carbonate platform.

Samples K1 and K2 collected from the clayey limestone unit are characterized by the following calpionellid species: Calpionella alpina, Calpionella minuta, Calpionella elliptica, Crassicollaria parvula, Tintinnopsella carpathica (both small and large forms), Tintinnopsella subacuta, Tintinnopsella longa, Lorenziella hungarica and Remaniella cadischiana. Thus, the unit is of latest early Berriasian age (i.e., the Elliptica Subzone of the Calpionella Zone). Berriasian age of the top of the Slivnitsa Formation and its cover in the neighbouring Beledie Han section was assumed by Sapunov et al. (1985) and Nikolov and Tzankov (1998) on the basis of the calcareous algal species Cayeuxia kurdistanensis Elliott, 1956 that is a longer-ranging microfossil (Berriasian to Albian; see Omaña et al., 2016). Our present calpionellid results provide a more precise age determination.

\section{Tectonically altered Salash-Cherni Osam Formation}

During the geological mapping of the area in scale 1:50 000, L. Metodiev described a body of alternating shales, marlstones and clayey limestones affected by tectonic alteration. This body was attributed by Metodiev to the Salash-Cherni Osam Formarion. It crops out along the eastern cutting of the Golyanovtsi-Dragovishtitsa road. Under the microscope, the samples (F1, F2, F3) taken for thin-sections revealed recrystalization of the primary carbonate matrix and almost complete lack of determinable microfossils. Due to the alteration, it was impossible to acquire data for age determination and microfacies identification for interpretation of the depositional environment.

\section{MICROFACIES ANALYSIS}

A detailed sedimentological study was performed on 52 thin-sections collected through the TithonianBerriasian sections north of Dragovishtitsa Village (sections Dragovishtitsa 1, Dragovishtitsa 2 and Dragovishtitsa East). Eight microfacies types (MFT 1MFT 8) have been identified. Some of them are compared to the Wilson's Standard Microfacies Scheme expanded by Flügel (2004). Two groups of microfacies are described below: Tithonian (MFT 1-MFT 3) and Berriasian (MFT 4-MFT 8).

\section{Tithonian microfacies}

In this study, three deep-water to shallow-marine microfacies types (MFT 1-MFT 3) have been recognized within the lower to upper Tithonian deposits of the Gintsi, Glozhene-Slivnitsa and Slivnitsa formations. The Gintsi Formation consists of grey to pinkish-grey mostly medium-bedded and commonly nodular limestones (Fig. 9a). The Tithonian part of the Glozhene-Slivnitsa Formation consists of grey, thinto medium-bedded limestones (Fig. $9 b$ ).

\section{MFT 1 Bioclastic wackestone/packstone}

Description: This microfacies is characterized by the presence of various bioclasts (Fig. 10a, $b$ ) including calpionellids, calcified radiolarians, whole juvenile ammonites, aptychi, calcified sponge spicules, echinoid spines, Globochaete alpina Lombard, 1945, commonly broken Saccocoma crinoids, thin-shelled ostracods, calcareous dinoflagellate cysts, brachiopods and scarce benthic foraminifera. Peloids also occur but are only locally abundant. The rock matrix is micritic or recrystallized to microsparite. Sometimes, it appears mottled due to burrowing. MFT 1 is commonly represented in the Gintsi and Glozhene-Slivnitsa formations only in the Dragovishtitsa 1 section.

Interpretation: The skeletal association (radiolarians, calpionellids, ammonites, sponge spicules, Globochaete alpina, calcareous dinoflagellate cysts) indicates an open-marine, deep-water environment. Benthic foraminifera and some of the broken skeletal grains (Saccocoma crinoids, brachiopod shells, etc.) were probably transported from other parts of the 

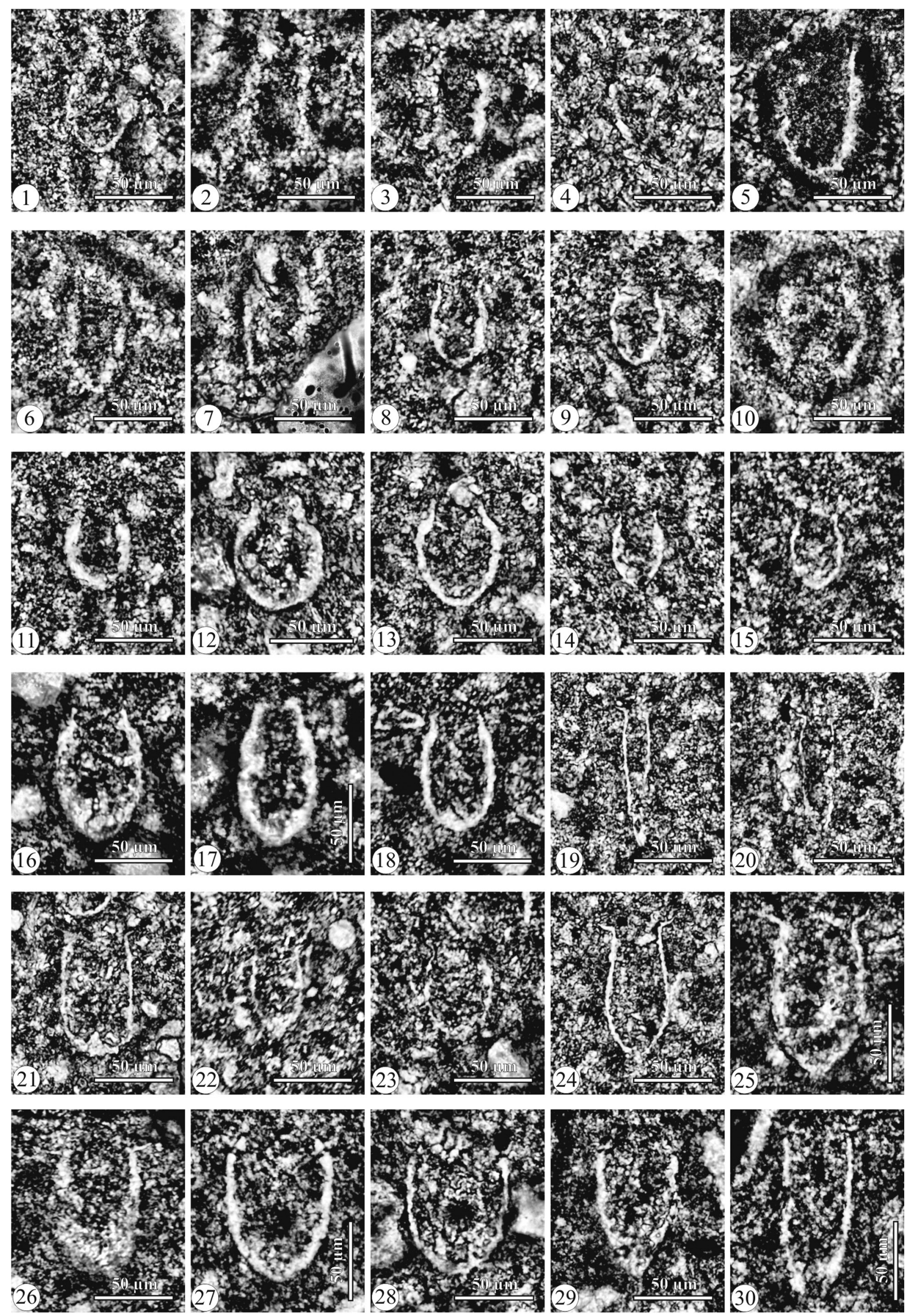
Fig. 8. Calpionellids of the Dragovishtitsa East section: 1) Tintinnopsella cf. remanei, sample 408, (the specimen is resedimented); 2, 3) Crassicollaria cf. intermedia, sample 402; 4) Crassicollaria cf. brevis, sample 408, (the specimen is resedimented); 5) Crassicollaria massutiniana, sample 402 (the specimen is resedimented); 6, 7) Crassicollaria colomi, sample 404; 8, 9) Crassicollaria parvula, sample 408; 10) Calpionella grandalpina, sample 402 (the specimen is resedimented); 11-13) Calpionella alpina, sample 406 (11), sample $408(12,13) ; 14,15)$ Calpionella minuta, sample 408; 16) Calpionella sp. A, sample 411; 17, 18) Calpionella elliptica, sample 411 (17), sample 413 (18); 19, 20) Tintinnopsella subacuta, sample 408; 21) Tintinnopsella longa, sample 408; 22, 23) Tintinnopsella carpathica (small forms), sample 408 (22), sample 409 (23); 24, 25) Tintinnopsella carpathica (large forms), sample 408 (24), sample 414 (25); 26) Remaniella borzai, sample 414; 27) Remaniella ferasini, sample 410; 28) Remaniella colomi, sample 414; 29, 30) Remaniella cadischiana, sample 414.

basin during periods of stronger storm activity. The micritic matrix and bioturbation fabrics characterize a setting with low sedimentation rates and predominant low-energy hydrodynamic conditions. The carbonate deposits of MFT 1 are interpreted as formed below the storm wave base.

\section{MFT 2 Bioclastic wackestone intercalated with intraclastic-bioclastic grainstone layers}

Description: MFT 2 consists of bioclastic wackestones containing irregular layers and lenses of bioclastic grainstones (Fig. 10c, d). The wackestones are composed of the same skeletal grains as in MFT 1, which are scattered within dark brown micritic matrix. The grainstone layers are represented by strongly micritized bioclasts (crinoids, brachiopods, calcareous green algae, Crescentiella morronensis (Crescenti, 1969) (formerly Tubiphytes morronensis crescenti), benthic foraminifera, ostracods and echinoid spines). Micritic intraclasts with elongate or irregular shapes and size between $0.02 \mathrm{~mm}$ and $1.00 \mathrm{~mm}$ are locally abundant. Peloids and single ooids also occur. The rock groundmass is represented by blocky and drusy calcite cements. Syntaxial calcite overgrowths are observed around some echinoderm fragments. Rounded and abraded skeletal grains also occur. The sediments of MFT 2 are only scarcely documented in close association with MFT 1 in the Gintsi and GlozheneSlivnitsa formations from the Dragovishtitsa 1 section.

Interpretation: The bioclastic wackestones are regarded as products of open-marine and low-energy deep-water sedimentation. On the other hand, the winnowed limestone texture, micritic intraclasts and fossil association (calcareous green algae, benthic foraminifera, ostracods, crinoids, brachiopods, echinoids) of the grainstone layers characterize a high-energy shallowmarine environment with normal salinity and open circulation. They are interpreted as allochthonous shallow-marine components, which were redeposited in a deeper-water marine setting. The sediments of MFT 2 are interpreted as formed below the storm wave base.

\section{MFT 3 Peloid-ooid packstone and grainstone}

Description: This MFT is composed of common peloids and micritic ooids (Fig. 10e-h) associated with rare bioclasts (benthic foraminifera, calcareous green algae, calcareous dinoflagellate cysts, ostracods, calcified radiolarians, ammonites, echinoderms) and micritic intraclasts. Ammonite shells (Fig. 10f) are filled with bioclastic wackestones of MFT 1. Well-rounded micritic intraclasts (bioclastic wackestones and mudstones with calpionellids) are also locally observed. The ooids are characterized by mostly sphaerical shapes and range in size between $0.10 \mathrm{~mm}$ and $0.60 \mathrm{~mm}$. The ooid cortexes are strongly micritized and locally display poorly preserved concentric laminae (Fig. 10g). The nuclei consist of calpionellids, Globochaete alpina, shell detritus and micritic intraclasts. The rock groundmass is represented by drusy sparitic cement. Bladed marine-phreatic cement locally forms isopachous rims around some ooids (Fig. 10e), and syntaxial calcite overgrowths are observed around echinoderm fragments. Allochems are moderately to poorly sorted. This microfacies is commonly reported from the Slivnitsa Formation in the Dragovishtitsa East section.

Interpretation: The abundant ooids, well-rounded micritic intraclasts and winnowed grainstone textures characterize a shallow-marine environment with predominant high-energy conditions. A part of the skeletal grains (e.g., ammonites, calcareous dinoflagellate cysts, radiolarians, calpionellids, Globochaete alpina) were probably transported from deeper parts of the basin and redeposited in the agitated shallow-marine environment during storm events. The sediments of MFT 3 are interpreted as deposited near or above the fair-weather wave base. This MFT can be compared to SMF 15 "Oolite" (Flügel, 2004).

\section{Lower Berriasian microfacies}

Berriasian microfacies from the Dragovishtitsa 1, Dragovishtitsa 2 and Dragovishtitsa East sections are sub- 

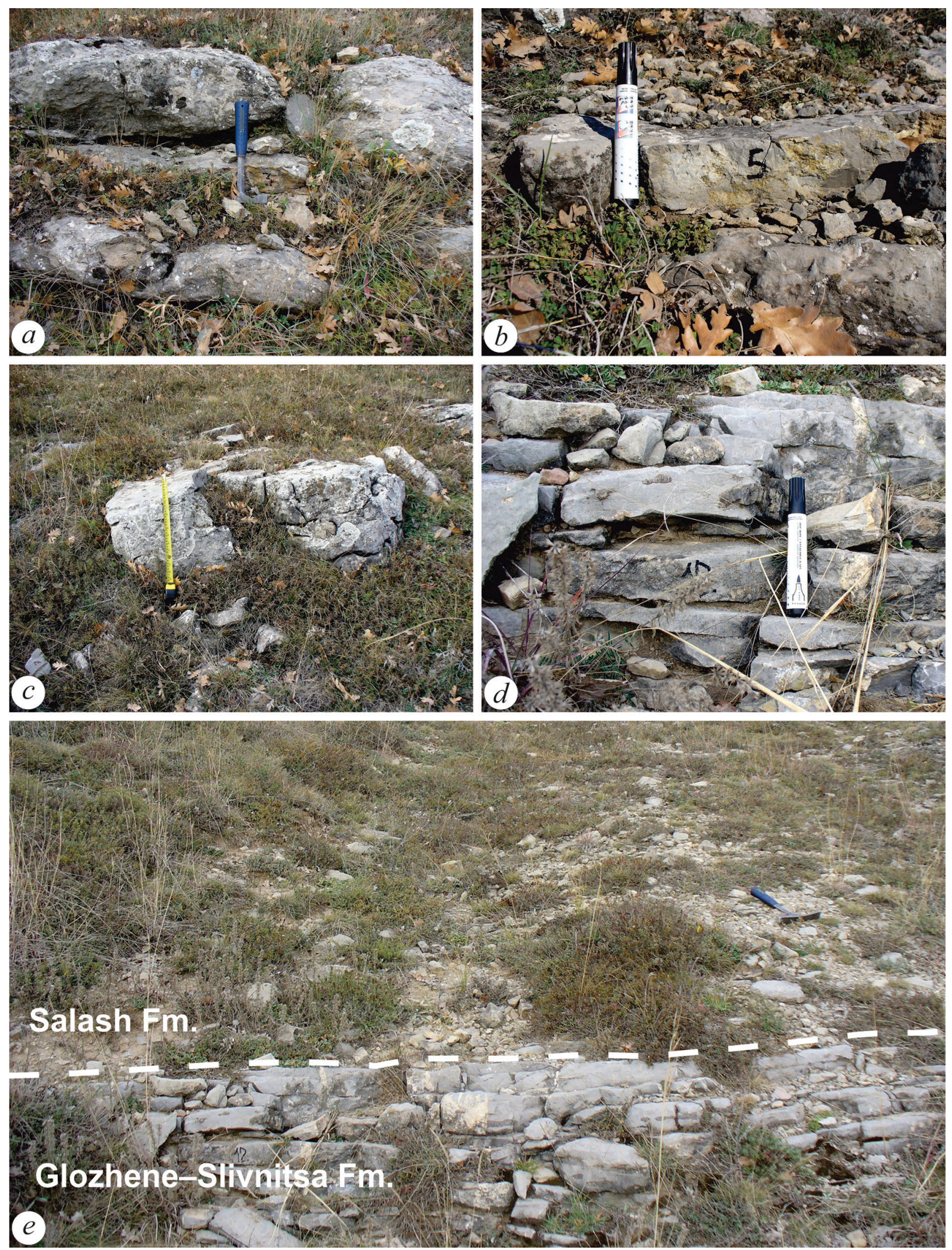

Fig. 9. Views from the Dragovishtitsa 1 and Dragovishtitsa 2 sections: $a$ ) Dark grey thin- to medium-bedded limestones of the Gintsi Fm. (upper Tithonian), Dragovishtitsa 1 section; $b$ ) Dark grey thin-bedded limestones of the Glozhene-Slivnitsa Fm. (upper Tithonian), Dragovishtitsa 1 section; c) Light grey medium- to thick-bedded limestones from the lower parts of the Glozhene-Slivnitsa Fm. (lower Berriasian), Dragovishtitsa 1 section; $d$ ) Thin-bedded grey limestones from the uppermost part of the Glozhene-Slivnitsa Fm. (lower Berriasian), Dragovishtitsa 2 section; $e$ ) the carbonate sediments around the boundary between the Glozhene-Slivnitsa Fm. and the Salash Fm. (lower Berriasian), Dragovishtitsa 2 section. 
divided into two groups: 1) microfacies deposited between the fair-weather wave base and the storm wave base; and 2) microfacies types deposited below the storm wave base.

Microfacies types from the first group occur in the Glozhene-Slivnitsa Formation (Figs $9 c-e, 11 a-c$ ) and are interpreted as a result of storm-influenced sedimentation. These tempestites are characterized by erosive lower bed surfaces, variable bed thicknesses and locally represented oscillation symmetrical ripples (Fig. 11a-c). Under the microscope, they are composed of bioclastic packstones and rudstones with large benthic foraminifera and Lithocodium-Bacinella (MFT 4), intraclastic-bioclastic packstone/grainstones (MFT 5) and peloid-bioclastic wackestones and wackestones/packstones (MFT 6).

The second microfacies group (deposited below the storm wave base) is represented only in the Salash Formation (Fig. 9e), which consists of thin-bedded limestones (MFT 7 and MFT 8) locally interbedded with marlstones, siltstones and sandstones.

\section{MFT 4 Bioclastic packstone and rudstone with large benthic foraminifera and Lithocodium- Bacinella}

Description: MFT 4 consists of large benthic foraminifera [mainly trocholinids, such as Andersenolina alpina (Leupold, 1935) and Protopeneroplis ultragranulata (Gorbatchik, 1971) - Fig. 12a; Andersenolina delphinensis (Arnaud-Vanneau, Boisseau and Darsac, 1988) - Fig. 13b; and lituolids, e.g., Pseudocyclammina lituus (Yokohama, 1890) with complex inner structures - Fig. 12b)] and Lithocodium-Bacinella (Figs $12 c, d, 13 a, b$ ), plus subordinately represented crinoids (Fig. 12f), small benthic foraminifera, brachiopods, pelecypods, gastropods (Fig. 12e), rare calcareous green algae, echinoid spines, Crescentiella morronensis, bryozoans, scarce calpionellids and calcified radiolarians. Most of the skeletal grains are strongly micritized or have variable in thickness micritic coatings. Peloids are locally common and well-rounded micritic intraclasts (Fig. 12g) are also observed. The groundmass is represented by micritic/microsparitc matrix or rare sparitic cement. Some echinoderm fragments display syntaxial calcite overgrowths. MFT 4 occurs in the Glozhene-Slivnitsa Formation in Dragovishtitsa 1, Dragovishtitsa 2 and in the Dragovishtitsa East section.

Interpretation: Most of the skeletal grains (Lithocodium-Bacinella, trocholinids, crinoids, brachiopods, pelecypods, gastropods, etc.) are indicative of shallowmarine setting with normal salinity and open water circulation. The abundant Lithocodium aggregatum Elliott, 1956 and Bacinella irregularis Radoičič, 1959 occupied a wide range of tropical and sub-tropical settings including supratidal algae mats and subtidal reefs (Rameil et al., 2010). The scarce calpionellids and radiolarians are interpreted as transported and redepos- ited from deeper parts of the basin by stronger storms and currents. The packstone and rudstone textures, as well as the locally represented well-rounded micritic intraclasts, characterize high-energy conditions.

\section{MFT 5 Intraclastic-bioclastic packstone/ grainstone}

Description: MFT 5 consists of packstones/grainstones with common intraclasts (Fig. 13c, $d$ ) and various skeletal grains. The latter are micritized to various degrees and include Lithocodium-Bacinella, brachiopod shells, crinoids (Fig. 13c), small and large benthic foraminifera, mainly trocholinids, echinoid spines, pelecypods and bryozoans, plus rare calpionellids and calcified radiolarians. The intraclasts are mostly subrounded, varying in size (from $0.02 \mathrm{~mm}$ to $1.00 \mathrm{~cm}$ ) and were derived mostly from bioclastic wackestones of MFT 8 . The groundmass is represented by micritic matrix and drusy calcite cements. Syntaxial calcite overgrowths are also observed around some echinoderm bioclasts. The allochems are poorly sorted. MFT 5 occurs only in the Glozhene-Slivnitsa Formation in the Dragovishtitsa 2 section.

Interpretation: The grain-supported texture, fossil association (Lithocodium-Bacinella, crinoids, large benthic foraminifera and mollusk shells) and the commonly represented subrounded intraclasts suggest deposition in a high-energy shallow-marine setting with normal salinity and open water circulation. This MFT is interpreted as lag deposits represented in the lowermost parts of the tempestite successions (Fig. 10a, $b$ ).

\section{MFT 6 Peloid-bioclastic wackestone and wackestone/packstone}

Description: The deposits of MFT 6 consist of wackestones and wackestones/packstones with skeletal grains and variable amount of peloids (Figs $12 h, 13 e-h$ ). The fossil association is represented by calpionellids, calcified radiolarians (Fig. 13h), Globochaete alpina and calcified sponge spicules, as well as echinoderms, Crescentiella morronensis (Fig. 13f), thinshelled ostracods, brachiopod bioclasts, calcareous dinoflagellate cysts, rare small and large benthic foraminifera (mainly trocholinids Andersenolina alpina and Andersenolina delphinensis - Fig. 13f), bryozoans (Fig. $13 g$ ), sparse corals (Fig. 13e), Lithocodium-Bacinella and micritized calcareous green algae. Various amounts of clastic quartz and feldspar angular grains of silt and sand size also occur. The allochems are poorly sorted. Some calcified sponge spicules display parallel alignment (Fig. 13h). MFT 6 commonly occurs in the Glozhene-Slivnitsa Formation in the Dragovishtitsa 1 and Dragovishtitsa 2 sections.

Interpretation: The micritic matrix indicates nonagitated environment. The fossil association is represented by a mixture of skeletal grains that occupied 

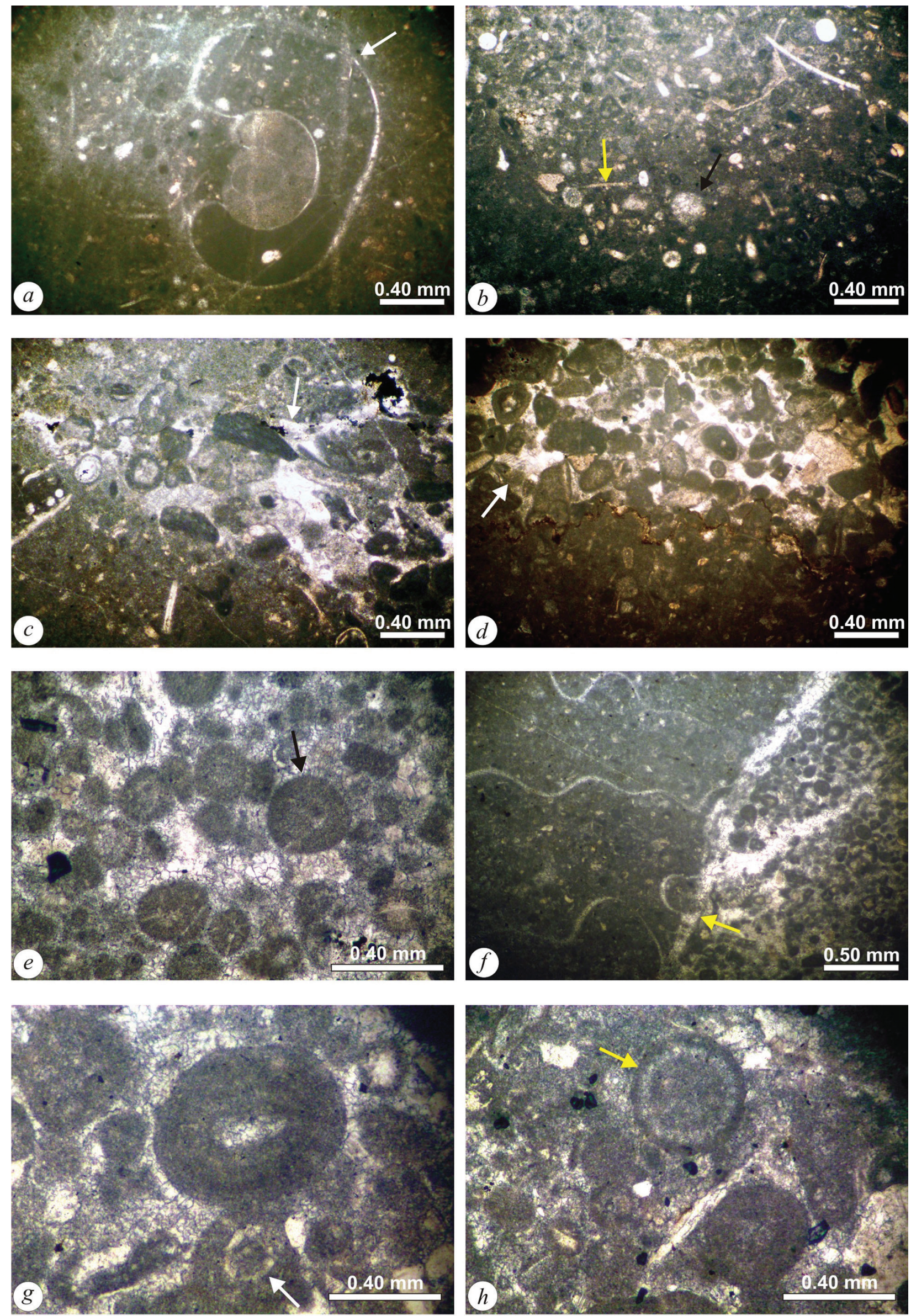
Fig. 10. Tithonian microfacies from the Gintsi, Glozhene-Slivnitsa and Slivnitsa formations: $a, b$ ) Bioclastic wackestone/packstone (MFT 1) containing whole ammonite shells (white arrow), calcified sponge spicules (yellow arrow) and calcified radiolarians (black arrow). Sample K 01, Gintsi Fm., Dragovishtitsa 1 section; $c, d$ ) MFT 2, Bioclastic wackestone intercalated with intraclastic-bioclastic grainstone layers (white arrows). Sample K 06b, Glozhene-Slivnitsa Fm., Dragovishtitsa 1 section; e) Ooid-peloidal grainstone (MFT 3) displaying relic bladed isopachous cement (black arrow). Sample 403, Slivnitsa Fm., Dragovishtitsa East section; f) MFT 3, redeposited ammonite shell (yellow arrow) filled with bioclastic wackestones of MFT 1. Sample 403, Slivnitsa Fm., Dragovishtitsa East section; $g$ ) Ooids with strongly micritized cortex, locally displaying poorly preserved concentric laminae (MFT 3). Some ooid nuclei consist of calpionellids (Calpionella grandalpina) (white arrow). Sample 404, Slivnitsa Fm., Dragovishtitsa East section; $h$ ) MFT 3, micritized calcareous algae bioclast (yellow arrow). Sample 404, Slivnitsa Fm., Dragovishtitsa East section. Note: All images in plane-polarized light.
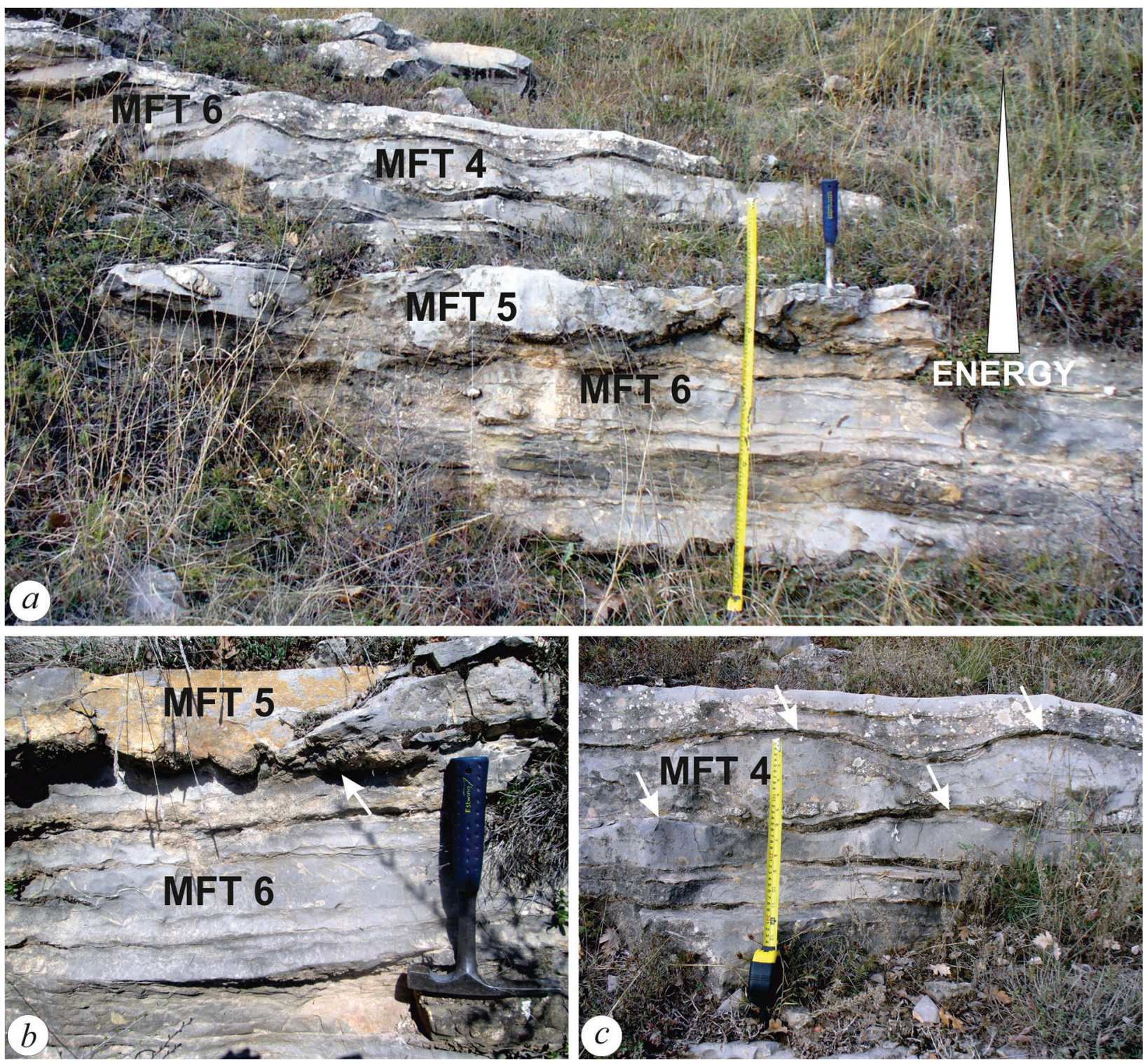

Fig. 11. Views of the base of the Dragovishtitsa 2 section: a) Carbonate tempestite sequence from the Glozhene-Slivnitsa Fm. that are characterized by erosive lower bed surfaces, constantly variable bed thickness and locally presented oscillation symmetrical ripples. Distinguished microfacies types (MFT 4-MFT 6) are also noted; $b$ ) Close view of erosive lower bed surface (white arrow); c) Close view of oscillation symmetrical ripples (white arrows). 

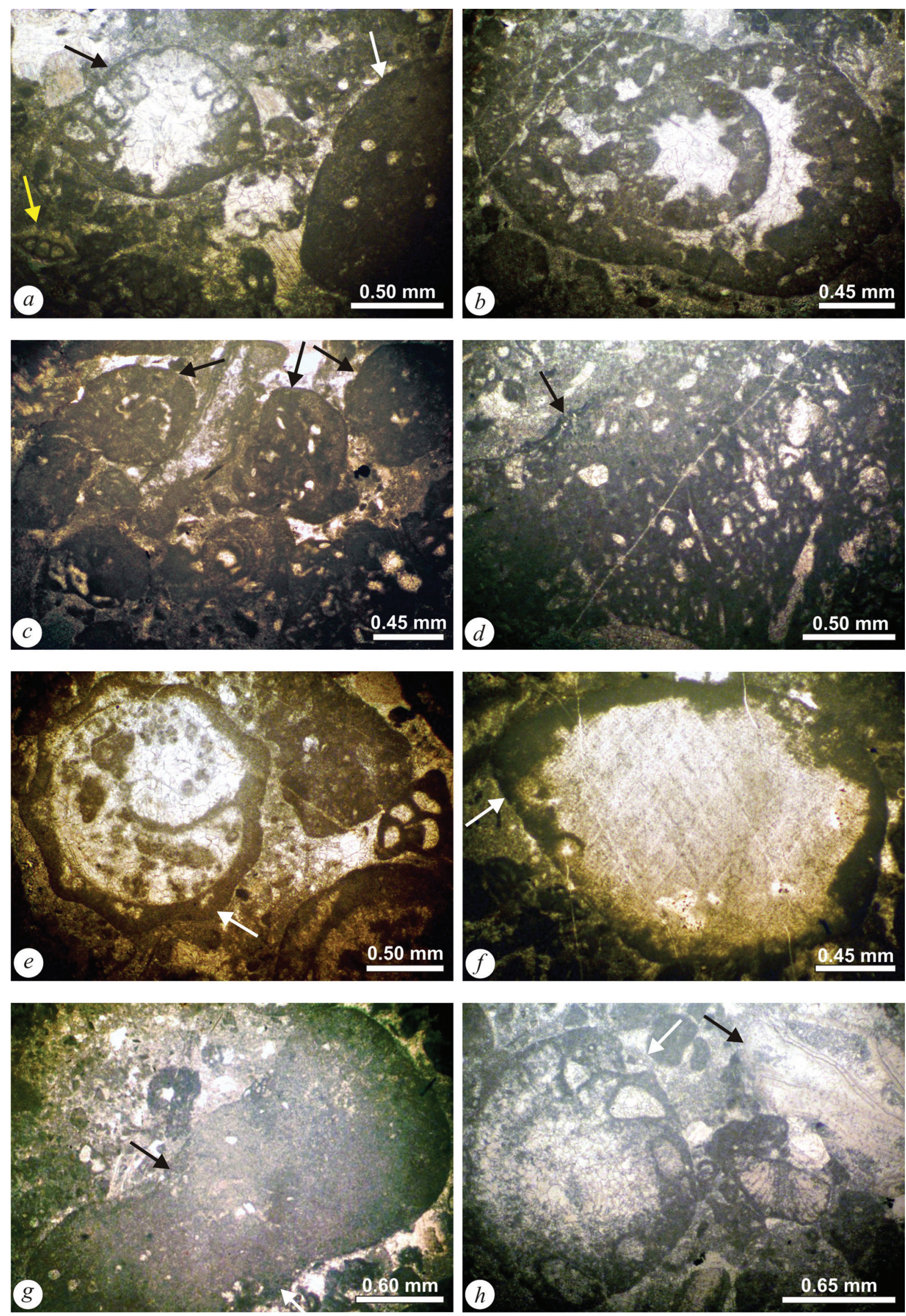
Fig. 12. Lower Berriasian microfacies from the Glozhene-Slivnitsa Formation: $a$ ) MFT 4, large benthic trocholinid foraminifera Andersenolina alpina (Leupold) (black arrow), Protopeneroplis ultragranulata (Gorbatchik) (yellow arrow) and Lithocodium bioclast (white arrow). Sample K 06e, Glozhene-Slivnitsa Fm., Dragovishtitsa 1 section; $b$ ) MFT 4, large benthic lituolid foraminifera with complex inner structures [Pseudocyclammina lituus (Yokohama)]. Sample K 06e, Glozhene-Slivnitsa Fm., Dragovishtitsa 1 section; $c, d$ ) MFT 4, Lithocodium-Bacinella bioclasts (black arrows). Samples K 06e and K 07, Glozhene-Slivnitsa Fm., Dragovishtitsa 1 section; $e$ ) MFT 4, micritized gastropod shell (white arrow). Sample K 06e, Glozhene-Slivnitsa Fm., Dragovishtitsa 1 section; f) MFT 4, Crinoid bioclast with irregular in thickness micritic coating (white arrow). Sample K 07, Glozhene-Slivnitsa Fm., Dragovishtitsa 1 section; $g$ ) MFT 4, well-rounded micritic intraclast (black arrow). Sample K 06e, Glozhene-Slivnitsa Fm., Dragovishtitsa 1 section; $h$ ) MFT 4, large benthic trocholinid foraminifera (white arrow) and bryozoan bioclast (black arrow). Sample 406, Glozhene-Slivnitsa Fm., Dragovishtitsa East section. Note: All images in plane-polarized light.

various shallow-marine (e.g., Lithocodium-Bacinella, trocholinids, bryozoans, micritized calcareous green algae) to deep-marine (calpionellids, Globochaete alpina, radiolarians, etc.) settings. The locally represented calcified sponge spicules displaying parallel alignment suggest the influence of storm-generated currents. The deposits of MFT 6 resulted from predominant calm-water sedimentation that was locally interrupted by storm-generated waves and currents.

\section{MFT 7 Fine-grained bioclastic-peloidal packstone/grainstone}

Description: MFT 7 (Fig. 14a,b) consists of very finegrained packstones/grainstones containing abundant peloids, small bioclasts and micritic intraclasts. Skeletal grains are represented by calcified siliceous sponge spicules, plus benthic foraminifera, rare calpionellids, calcified radiolarians, calcareous dinoflagellate cysts, thin-shelled ostracods, crinoids and echinoid spines. This MFT occurs rarely only in the lowermost part of the Salash Formation in the Dragovishtitsa 2 section. Clastic grains include sand-sized angular quartz and feldspar grains, as well as sporadic lithic fragments. The groundmass is composed of micritic matrix and sparitic cements. Syntaxial calcite overgrowths are observed around some echinoderm bioclasts.

Interpretation: The fossil association (calcified siliceous sponge spicules, calpionellids, radiolarians, calcareous dinoflagellate cysts, thin-shelled ostracods, etc.) indicates a relatively deep-water marine setting (Flügel, 2004). Packstones and grainstones consisting of peloids and small lithoclasts and bioclasts commonly occur in deeper basins, open-marine shelf and are abundantly represented in outer ramp settings (Flügel, 2004). This MFT is very similar to SMF 2: "Microbioclastic peloidal calcisiltite".

\section{MFT 8 Bioturbated bioclastic wackestone and wackestone/packstone}

Description: MFT 8 comprises wackestones and sporadic wackestones/packstones containing mainly finegrained pelagic microfossils (Fig. 14c-h). They are represented mostly by calpionellids (Fig. $14 d, f, h$ ) and calcified radiolarians (Fig. 14f), plus calcified sponge spicules (Fig. 14c), Globochaete alpina, echinoderm bioclasts, thin-shelled ostracods and rare calcareous dinoflagellate cysts, benthic foraminifera and brachiopod shell detritus. Whole ammonite shells and aptychi (Fig. $14 g, h$ ) are also observed. Peloids are scarce in some wackestones/packstones. Silt- to sand-sized clastic quartz and feldspar angular grains are variably represented (from $<5 \%$ to up to $10 \%$ ). Bioturbation fabrics are very common. Micritic matrix is characterized by inhomogeneous texture most probably due to burrowing (Fig. 14e, f). Variations in packing densities are often observed. MFT 8 is abundant in the Salash Formation in Dragovishtitsa 2 section and in the Salash-Cherni Osam Formation in the Dragovishtitsa East section.

Interpretation: The fossil assemblage, micritic matrix and common bioturbation suggest deposition in a deep-water, non-agitated setting with low sedimentation rate. MFT 8 can be correlated with SMF 1-Burrowed: "Burrowed bioclastic wackestone with abundant fine pelagic and benthic biodetritus" that occurs in basin and open-marine shelf settings, as well as in outer ramp environments.

\section{DISCUSSION}

\section{Calpionellid biostratigraphy}

The identification of 45 chitinoidellid and calpionellid species belonging to 15 genera of the three families (Chitinoidellidae Trejo, 1975, Semichitinoidellidae Nowak, 1978 and Calpionellidae Colom, 1948) in the three sections studied has allowed the recognition of the Chitinoidella, Praetintinnopsella, Crassicollaria and Calpionella zones. In the Dragovishtitsa 1 section, the Chitinoidella Zone is represented by the top-Dobeni Subzone and the whole Boneti Subzone and covers the sediments of upper parts of the Gintsi Formation and the base of the Glozhene-Slivnitsa Formation. The Praetintinnopsella Zone has been recorded only in this section. The Crassicollaria Zone (Remanei Subzone) is documented only in one 

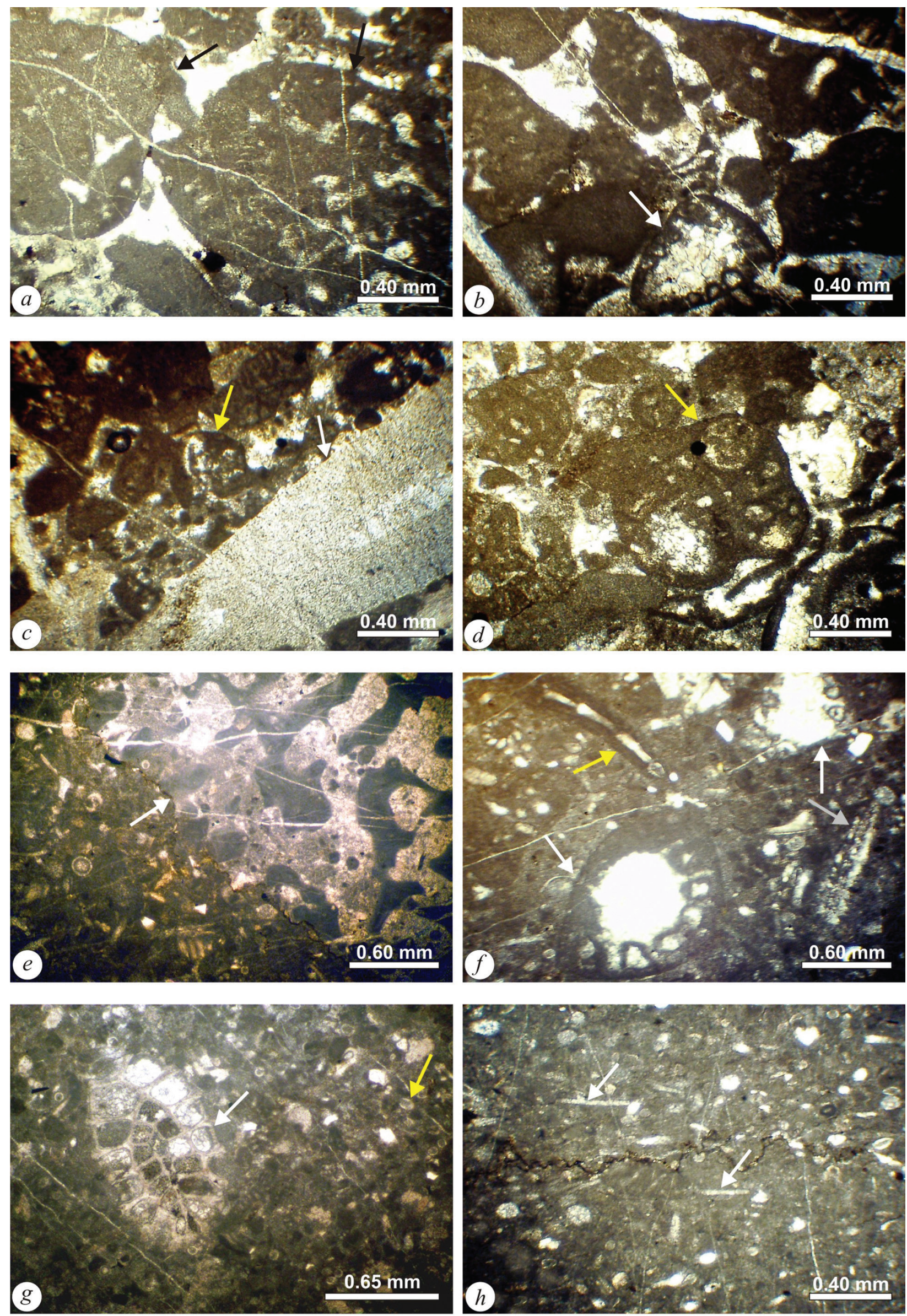
Fig. 13. Lower Berriasian microfacies from the Glozhene-Slivnitsa Formation: $a, b$ ) MFT 4, rudstone and packstone/grainstone containing common Lithocodium-Bacinella bioclasts (black arrows) and locally presented trocholinid foraminifera - Andersenolina delphinensis (Arnaud-Vanneau, Boisseau and Darsac) (white arrow). Sample L 3, Glozhene-Slivnitsa Fm., Dragovishtitsa 2 section; $c, d$ ) MFT 5, grainstone with rounded intraclasts (yellow arrows), originating from bioclastic wackestones of MFT 6 and large crinoid bioclast (white arrow). Sample L 2, Glozhene-Slivnitsa Fm., Dragovishtitsa 2 section; e) Coral bioclast (white arrow) within bioclastic wackestone of MFT 6. Sample K 08, Glozhene-Slivnitsa Fm., Dragovishtitsa 2 section; $f$ ) MFT 6, bioclastic wackestone with Crescentiella morronensis (Crescenti) (yellow arrow), micritized large benthic trocholinid foraminifera (white arrows) - Protopeneroplis ultragranulata (Gorbatchik) in left lower corner and Andersenolina alpina (Leupold) in upper right corner, and echinoid spine (gray arrow). Sample K 08, Glozhene-Slivnitsa Fm., Dragovishtitsa 2 section; g) MFT 6, peloid-bioclastic wackestone/packstone with bryozoan bioclasts (white arrow) and calpionellids; Calpionella alpina dominates over Calpionella elliptica (yellow arrow). Sample K 6f, Glozhene-Slivnitsa Fm., Dragovishtitsa 1 section; $h$ ) MFT 6, bioclastic wackestone with calcified sponge spicules (white arrows), displaying parallel alignment. Sample L 5, Glozhene-Slivnitsa Fm., Dragovishtitsa 2 section. Note: All images in plane-polarized light.

sample, just below the stratigraphic hiatus within the Glozhene-Slivnitsa Formation. The upper parts of the Crassicollaria Zone (Massutiniana Subzone) are connected with the top of the Slivnitsa Formation in the Dragovishtitsa East section. The Alpina Subzone of the Calpionella Zone has been indicated in the Glozhene-Slivnitsa Formation in the Dragovishtitsa East section, without its lower and upper boundaries. The Elliptica Subzone of the Calpionella Zone deserves special attention since it has been recorded in each section, but in different lithostratigraphic units: the Glozhene-Slivnitsa Formation (Dragovishtitsa 1 section), the Glozhene-Slivnitsa and Salash formations (Dragovishtitsa 2 section) and the Salash-Cherni Osam Formation (Dragovishtitsa East section), as well as in the clayey limestone unit that covers the Slivnitsa Formation at the highest parts of the Mezhdina Summit. It means that, during the mid-Berriasian (equivalent to the chron of the Elliptica Subzone), several important events took place: the deposition of the Glozhene-Slivnitsa Formation above a large stratigraphic gap, the drowning of the carbonate platform (Slivnitsa Formation) and the start of siliciclastic-carbonate sedimentation (Salash and Salash-Cherni Osam formations).

\section{Evolution of the Tithonian-Berriasian depositional environments}

The studied Tithonian-Berriasian carbonate deposits north of Dragovishtitsa Village were formed in various shallow to deep-marine settings, under high- to lowenergy conditions. Thus, during the early (the Dobeni Subzone of the Chitinoidella Zone) and late Tithonian (the Boneti Subzone of the Chitinoidella Zone, Praetintinnopsella Zone and the base of the Crassicollaria Zone), carbonate sedimentation in the Dragovishtitsa 1 section (i.e., Gintsi and Glozhene-Slivnitsa formations) took place in a non-agitated deep-water and open-marine environment with low sedimentation rates (MFT 1). Most probably, this setting was located below the storm wave base and was only sporadically affected by stronger storms and currents, when bioclastic wackestones with intraclastic-bioclastic grainstone layers of MFT 2 were formed. On the other hand, the upper Tithonian deposits (Crassicollaria Zone, Massutiniana Subzone) of the Slivnitsa Formation in the Dragovishtitsa East section, indicate an agitated shallow-marine setting, located near or above the fairweather wave base, with deposition of packstones and grainstones with abundant ooids and peloids (MFT 3).

A deepening-upward trend is recognized within the Berriasian interval of the succession. Thus, midBerriasian (the Elliptica Subzone of the Calpionella Zone) deposition occurred under predominantly high-energy conditions and strong storm influence (MFT 4-MFT 6), when various in thickness tempestite successions were formed between the fair-weather wave base and the storm wave base in the GlozheneSlivnitsa Formation (Dragovishtitsa 1, Dragovishtitsa 2 and Dragovishtitsa East sections).

Later on, in the upper part of the Elliptica Subzone (latest early Berriasian), a change of the depositional environment occurred, when the siliciclastic-carbonate succession of the Salash Formation (in Dragovishtitsa 2 section) and the Salash-Cherni Osam Formation (in Dragovishtitsa East section) were deposited in a deepwater marine setting (MFT 7 and MFT 8) below the storm wave base.

On the basis of the obtained sedimentological data, it can be assumed that the lower Berriasian succession was formed on a carbonate ramp, with welldistinguished storm-dominated mid-ramp zone (MFT 4 MFT 6 in the Glozhene-Slivnitsa Formation) and outer ramp zone (MFT 7 and MFT 8 in the Salash Formation) (cf. Burchette and Wright, 1992).

\section{Regional lithostratigraphy}

The area north of Dragovishtitsa Village provides large outcrops of the Slivnitsa Formation in the northern and western parts. There, the Slivnitsa Formation 

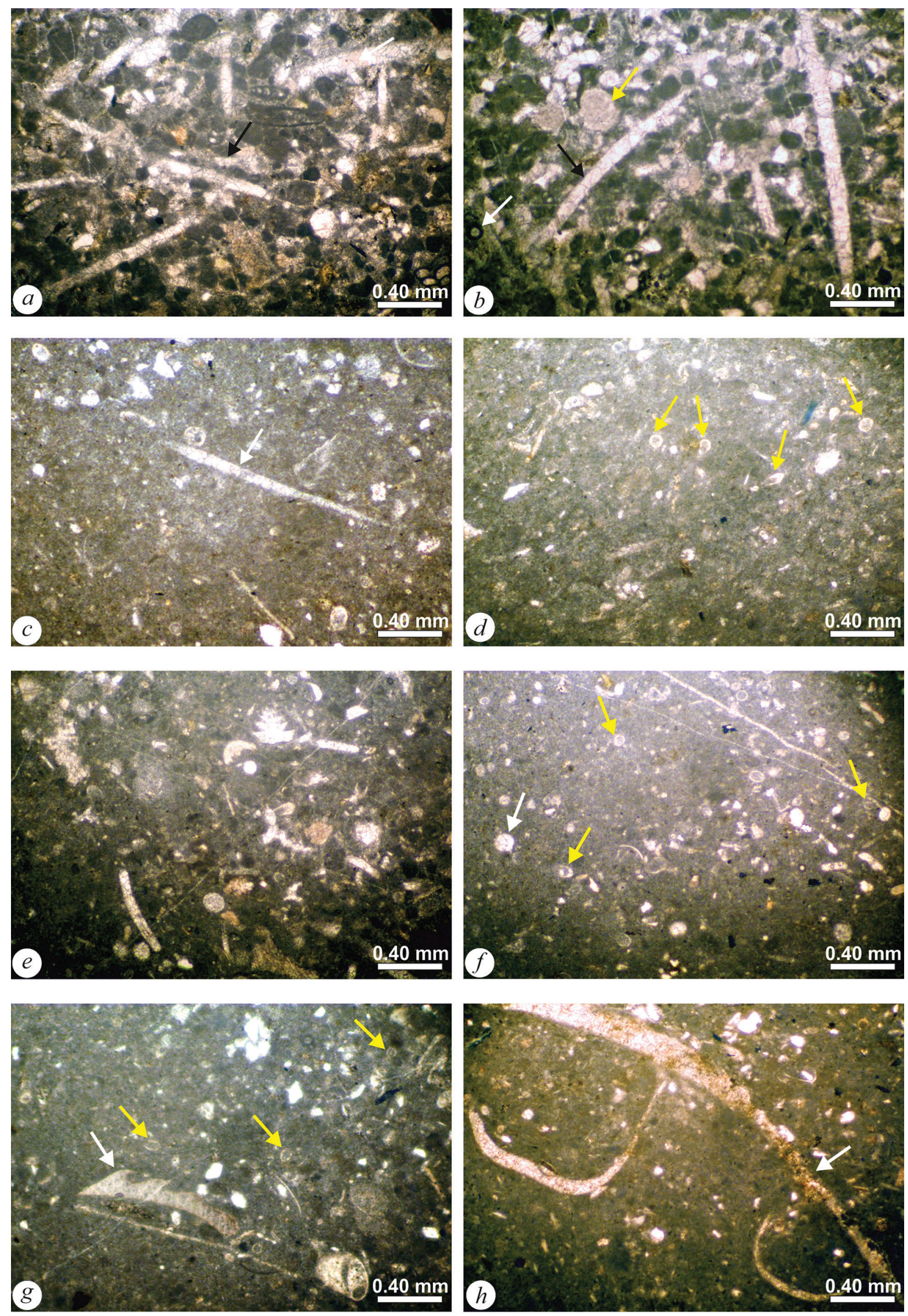
Fig. 14. Lower Berriasian microfacies from the Salash and Salash-Cherni Osam formations: $a, b$ ) MFT 7, fine-grained bioclasticpeloidal packstone and grainstone, containing calcified sponge spicules (black arrows), echinoderm bioclasts (yellow arrow) and calcareous dinocycts (white arrow). Sample K 13, Salash Formation, Dragovishtitsa 2 section; c) MFT 8, bioclastic wackestone containing calcified sponge spicules (white arrow). Sample 412, Salash-Cherni Osam Formation, Dragovishtitsa East section; d) MFT 8, bioclastic wackestone with common calpionellids (yellow arrows). Sample K 22, Salash Formation, Dragovishtitsa 2 section; e) MFT 8, bioclastic wackestone with bioturbation fabric. Sample K 14, Salash Formation, Dragovishtitsa 2 section; f) MFT 8, bioturbated bioclastic wackestone with calpionellids Calpionella alpina and Tintinnopsella carpathica (yellow arrows) and calcified radiolarians (white arrow). Sample 413, Salash-Cherni Osam Formation, Dragovishtitsa East section; $g$ ) MFT 8, bioclastic wackestone containing aptychi (white arrow) and calpionellids, small and large forms of Tintinnopsella carpathica and Calpionella alpina (yellow arrows). Sample K 24, Salash Formation, Dragovishtitsa 2 section; $h$ ) MFT 8, part from ammonite shell (white arrow). Sample K 20, Salash Formation, Dragovishtitsa 2 section. Note: All images in plane-polarized light.

is covered by atypical Salash Formation (Sapunov et al., 1985). In northeastern direction, the Slivnitsa Formation passes both vertically and laterally into the Glozhene-Slivnitsa Formation of late Tithonian and early Berriasian age. The overlying Salash Formation corresponds to the mid-Berriasian (the Elliptica Subzone of the Calpionella Zone) and is characterized by the presence of calcareous sandstones. Farther east, the Salash-Cherni Osam Formation in the Dragovishtitsa East section represents coeval and more distal equivalent of the Salash Formation. A small portion of the Slivnitsa Formation is here dated as late Tithonian; however, the chronostratigraphic range of this formation in the eastern part of the Western Srednogorie [Beledie Han and Dragovishtitsa sections in Sapunov et al. (1985)] seems to be much larger. In any case, the top of the Slivnitsa Formation is not younger than mid-Berriasian. East of the study area, around Kremikovtsi Village, deposition of turbiditic sediments of the Neshkovtsi and Cherni Osam formations started earlier during the middle Kimmeridgian (Sapunov and Tchoumatchenco, 1995).

\section{Westward rejuvenation of the cover and drowning of the carbonate platform}

The shallow carbonate platform sediments of the Slivnitsa Formation in the western part of the Western Srednogorie Unit have been thoroughly studied both in terms of foraminifer biostratigraphy and carbonate microfacies (Ivanova, 1999; Ivanova and KolevaRekalova, 2004; Ivanova et al., 2008). These authors disclose the presence of a long-lived Callovian to Valanginian carbonate platform at the sites of Kalotina, Velinovo, Rebro and Lyalintsi. Additionally, it has been evidenced that in the Kalotina and Dragoman sections, the drowning of the carbonate platform occurred during the late Valanginian (Ivanova et al., 2000; Petrova et al., 2010). There, the Slivnitsa Formation is covered by hemipelagic limestone-marlstone rocks of the Salash Formation. Easterly, still in the western part of Western Srednogorie, in the Tri Ushi section, the carbonate platform drowned earlier, at the very end of the Berriasian (Ivanova et al., 2000; Petrova et al., 2010, 2011). In these three sections (Kalotina, Dragoman and Tri Ushi), the lithological boundary between the Slivnitsa and Salash formations is clearly marked by erosional surfaces, iron hydroxides and glaucony mineralization. It is only in the area of Dragovishtitsa Village, here studied, where the boundary between the Slivnitsa Formation and the clayey limestone unit represents an abrupt lithological contact, manifested in change of colour and bed thickness. The drowning of the carbonate platform is highly diachronous, from mid-Berriasian at Dragovishtitsa area to top Berriasian at Tri Ushi, to late Valanginian at Dragoman and Kalotina. Similar events have recently been described from the Getic carbonate platform of the Southern Carpathians in Romania (Grădinaru et al., 2016). The tectonic control expressed by normal faults of the passive margin can best explain the diachroneity and the variability of the sediments overlying the drowning unconformity in the Western Srednogorie of Bulgaria.

\section{CONCLUSIONS}

The main results of this study are as follows:

1) In the eastern part of the Western Srednogorie Unit, around Dragovishtitsa Village, a specific succession of the Gintsi and Glozhene-Slivnitsa formations has provided micropalaeontological evidence of late Tithonian (Chitinoidella, Praetintinnopsella and Crassicollaria zones) and mid-Berriasian (the Elliptica Subzone of the Calpionella Zone) age on the basis of 45 chitinoidellid and calpionellid species. A significant stratigraphic hiatus is documented within the Glozhene-Slivnitsa Formation, since the Crassicollaria Zone, as well as the Alpina+Remaniella subzones of the Calpionella Zone, is absent from the succession. The conformably overlying Salash Formation is of mid-Berriasian age (the Elliptica Subzone of the Calpionella Zone) and is locally characterized by the presence of calcareous sandstones.

2) The presence of specific transional depositional settings, from carbonate platform to deeper-marine environment, has led to deposition of specific lithostrati- 
graphic units not always corresponding to the diagnostic features of the Glozhene, Salash and Cherni Osam formations.

3) The Salash-Cherni Osam Formation, as well as the clayey limestone unit that covers the Slivnitsa Formation, is mid-Berriasian in age [the Elliptica Subzone (pars.) of the Calpionella Zone]. The Slivnitsa and Glozhene-Slivnitsa formations that underlie the Salash-Cherni Osam Formation in the Dragovishtitsa East section correspond to the Massutiniana Subzone (pars.) of the Crassicollaria Zone and the Alpina Subzone (pars.) of the Calpionella Zone, respectively. Reworking of calpionellids from the Crassicollaria Zone is documented in the Alpina and Elliptica subzones in the Dragovishtitsa 1, Dragovishtitsa 2 and Dragovishtitsa East sections.

4) Eight microfacies have been distinguished, suggestting that the sediments were deposited under carbonate platform, rather than basin pelagic, conditions. The upper parts of the studied sections reveal an upward-deepining depositional trend.

5) The Slivnitsa Formation is covered by highly diachronous sediments of more distal settings: from mid-Berriasian around Dragovishtitsa Village to the Berriasian/Valanginian transition in the Tri Ushi section to late Valanginian in the Dragoman and Kalotina sections. This fact, together with the significant stratigraphic hiatus within the GlozheneSlivnitsa Formation, is considered as tectonically controlled.

\section{Acknowledgements}

Iskra Lakova thanks Profs Ivo Sapunov and Platon Tchoumatchenco (Geological Institute, Sofia) for previous joint fieldwork in the area. The authors are grateful to Yavor Stefanov for useful comments concerning tempestite deposits. We thank Drs Athanas Chatalov (Sofia University) and Diego A. Kietzmann (Universidad de Buenos Aires) for critical reviews and useful comments. Dr Georgi Granchovski (Geological Institute, Sofia) made a significant improvement on the text. This study is financially supported by the Bulgarian NSF under the contract DNTS Slovakia $01 / 9$ and the Slovakian Research and Development Agency under the contract APVV-14-0118.

\section{APPENDIX. TAXONOMIC LIST}

An alphabetic list of all chitinoidellid and calpionellid taxa mentioned in text and figures is given below. See Furrazola Bermúdez (1965), Borza (1969), Furrazola Bermúdez and Kreisel (1973), Pop (1994a, b, 1996, 1997b, 1998), Grün and Blau (1996), Reháková (1998, 2002), Sallouhi et al. (2011) and references therein for information concerning taxonomy and authorship.

Chitinoidellids and semichitinoidellids:

Almajella Pop, 1998

Almajella cristobalensis (Furrazola Bermúdez, 1965)

Borziella Pop, 1997

Borziella slovenica (Borza, 1969)

Carpathella Pop, 1998

Carpathella rumanica Pop, 1998

Chitinoidella Doben, 1963

Chitinoidella boneti Doben, 1963

Chitinoidella carthagensis Sallouhi, Boughdiri and

Cordey, 2011

Chitinoidella elongata Pop, 1997

Chitinoidella hegarati Sallouhi, Boughdiri and

Cordey, 2011

Chitinoidella popi Sallouhi, Boughdiri and Cordey, 2011

Chitinoidella sp.

Daciella Pop, 1998

Daciella almajica Pop, 1998

Daciella banatica Pop, 1998

Daciella danubica Pop, 1998
Daciella svinitensis Pop, 1998

Daciella sp.

Dobeniella Pop, 1997

Dobeniella bermudezi (Furrazola Bermúdez, 1965)

Dobeniella colomi (Borza, 1966)

Dobeniella cubensis (Furrazola Bermúdez, 1965)

Dobeniella pinarensis (Furrazola Bermúdez and

Kreisel, 1973)

Dobeniella tithonica (Borza, 1969)

Longicollaria Pop, 1997

Longicollaria dobeni (Borza, 1966)

Longicollaria insueta (̌̌ehánek, 1986)

Popiella Reháková, 2002

Popiella oblongata Reháková, 2002

Praetintinnopsella Borza, 1969

Praetintinnopsella andrusovi Borza, 1969

Calpionellids:

Borzaiella Grün and Blau, 1996

Borzaiella atava Grün and Blau, 1996

Calpionella Lorenz, 1902

Calpionella alpina Lorenz, 1902

Calpionella elliptica Cadisch, 1932

Calpionella grandalpina Nagy, 1986

Calpionella minuta Houša, 1990

Calpionella sp. A

Crassicollaria Remane, 1962 
Crassicollaria cf. brevis Remane, 1962

Crassicollaria colomi Doben, 1963

Crassicollaria cf. intermedia (Durand Delga, 1957)

Crassicollaria massutiniana (Colom, 1948)

Crassicollaria parvula Remane, 1962

Lorenziella Knauer and Nagy, 1963

Lorenziella hungarica Knauer and Nagy, 1963

Remaniella Catalano, 1965

Remaniella borzai Pop, 1994

Remaniella cadischiana (Colom, 1948)
Remaniella catalanoi Pop, 1996

Remaniella colomi Pop, 1996

Remaniella ferasini (Catalano, 1965)

Tintinnopsella Colom, 1948

Tintinnopsella carpathica (Murgeanu and Filipescu, 1933)

Tintinnopsella doliphormis (Colom, 1939)

Tintinnopsella longa (Colom, 1939)

Tintinnopsella subacuta (Colom, 1948)

Tintinnopsella cf. remanei Borza, 1969

\section{REFERENCES}

Benzaggagh, M., Cecca, F., Rouget, I. 2010. Biostratigraphic distribution of ammonites and calpionellids in the Tithonian of the internal Prerif (Msila area, Morocco). Paläontologische Zeitschrift 84 (2), 301-315.

Borza, K. 1969. Die Mikrofazies und Mikrofossilien des Oberjuras und der Unterkreide der Klippen Zone der Westkarpaten. Slovak Academy of Sciences Publishing House, Bratislava, $302 \mathrm{pp}$.

Boughdiri, M., Sallouhi, H., Haddad, S., Cordey, F., Soussi, M. 2009. Integrated biostratigraphy and regional correlations of Upper Jurassic-lowermost Cretaceous series in northern Tunisia. GFF 131 (1), 71-81.

Burchette, T.P., Wright, V.P. 1992. Carbonate ramp depositional systems. Sedimentary Geology 79, 3-35.

Cecca, F., Enay, R., Le Hégarat, G. 1989. L'Ardescien (Tithonique supérieur) de la région stratotypique: séries de référence et faunes (ammonites, calpionelles) de la bordure ardéchoise. Documents Laboratoires de Géologie Lyon 107, $1-115$.

Dabovski, Ch., Zagorchev, I. 2009. Introduction: Mesozoic evolution and Alpine structure. In: Zagorchev, I., Dabovski, Ch., Nikolov, T. (Eds), Geology of Bulgaria. Vol. II. Mesozoic geology. "Prof. Marin Drinov" Academic Press, Sofia, 15-37.

Dunham, R.J. 1962. Classification of carbonate rocks according to depositional texture. In: Ham, W.E. (Ed), Classification of carbonate rocks. American Association of Petroleum Geologists, Memoir 1, 108-171.

Enay, R., Geyssant, J.R. 1975. Faunes tithoniques des chaînes bétiques (Espagne méridionale). Colloque sur la limite jurassique-crétacé, Lyon-Neuchâtel, 1973. Mémoires de Bureau de Recherches Géologiques et Minières 86, 39-55.

Flügel, E. 2004. Microfacies of Carbonate Rocks. Springer, Berlin, 976 pp.

Furrazola Bermúdez, G. 1965. Tres nuevas especies de tintinidos del Jurásico superior de Cuba. Instituto cubano recursos minerales, Publicación especial 2, 3-39.

Furrazola Bermúdez, G., Kreisel, K. 1973. Los tintinidos fósiles de Cuba. Revista tecnológica 1 (73), 27-45.

Grabowski, J., Lakova, I., Petrova, S., Stoykova, K., Ivanova, D., Wójcik-Tabol, P., Sobień, K., Schnabl, P. 2016. Palaeomagnetism and integrated stratigraphy of the Upper Berriasian hemipelagic succession in Barlya section Western Balkan, Bulgaria: Implications for lithogenic input and palaeoredox variations. Palaeogeography, Palaeoclimatology, Palaeoecology 461, 156-177.
Grădinaru, M., Lazar, I., Bucur, I.I., Grădinaru, E., Săsăran, E., Ducea, M.N., Andrăşanu, A. 2016. The Valanginian history of the eastern part of the Getic Carbonate Platform (Southern Carpathians, Romania): Evidence for emergence and drowning of the platform. Cretaceous Research $66,11-42$.

Grün, B., Blau, J. 1996. Phylogenie, systematik und biostratigraphie der Calpionellidae Bonet, 1956: Neue daten aus dem Rosso ammonitico superiore und dem Biancone (Oberjura/ Unterkreide: Tithon-Valangin) von Ra Stua (Prov. Belluno, Italien). Revue de Paléobiologie 15 (2), 571-595.

Ivanova, D. 1999. Middle Callovian to Valanginian microfossil biostratigraphy in the West Balkan Mountain, Bulgaria (SE Europe). Acta Palaeontologica Romaniae 2, 231-236.

Ivanova, D., Koleva-Rekalova, E. 2004. Agglutinated foraminifers in the framework of Southwestern Bulgarian palaeoenvironmental evolution during the Late Jurassic and Early Cretaceous. In: Bubík, M., Kaminski, M.A. (Eds), Proceedings of the Sixth International Workshop on Agglutinated Foraminifera, Grzybowski Fondation Special Publication 8, 217-227.

Ivanova, D., Stoykova, K., Lakova I. 2000. New microfossil data on the age relationship between Slivnitsa and Salash Formation in Dragoman region, Western Bulgaria. Comptes rendus de l'Académie bulgare des Sciences 53 (4), 77-81.

Ivanova, D., Kołodzej, B., Koleva-Rekalova, E., Roniewicz, E. 2008. Oxfordian to Valanginian palaeoenvironmental evolution of the western Moesian Platform: a case study from SW Bulgaria. Annales Societatis Geologorum Poloniae 78, 65-90.

Kietzmann, D.A. 2017. Chitinoidellids from the Early Tithonian-Early Valanginian Vaca Muerta Formation in the Northern Neuquén Basin, Argentina. Journal of South American Earth Sciences 76, 152-164.

Lakova, I., Petrova, S. 2013. Towards a standard Tithonian to Valanginian calpionellid zonation of the Tethyan Realm. Acta Geologica Polonica 63 (2), 201-221.

Lakova, I., Stoykova, K., Ivanova., D. 1999. Calpionellid, nannofossil and calcareous dinocyst bioevents and integrated biochronology of the Tithonian to Valangian in the Western Balkanides, Bulgaria. Geologica Carpathica 50 (2), 151-168.

Mandov, G. 1967. Sur la transgression Hauterivienne au nord du village Dragoman, environs de Sofia. Annuaire de l'Université de Sofia, Faculté de Géologie et Géographie 60 (1), 145-152 (in Bulgarian, with French abstract). 
Mandov, G. 1970. Sur la stratigraphie du Crétacé inférieur dans la partie sud de la régiou Zabardé (Bulgarie d'Ouest). Annuaire de l'Université de Sofia, Faculté de Géologie et Géographie 62 (1), 59-71 (in Bulgarian, with French abstract).

Mandov, G. 1976. L'étage Hauterivien dans les Balkanides occidentals (Bulgarie de l'ouest) et sa faune d'ammonites. Annuaire de l'Université de Sofia, Faculté de Géologie et Géographie 67 (1), 11-90 (in Bulgarian, with French abstract).

Mandov, G., Nikilov, T. 2001. Stratigraphy of the Lower Cretaceous in the region between Dragoman and Kalotina villages, Sofia district (Western Bulgaria). Annuaire de l'Université de Sofia, Faculté de Géologie et Géographie 91 (1), 5-26 (in Bulgarian, with English abstract).

Michalík, J., Lintnerová, O., Reháková, D., Boorová, D., Šimo, V. 2012. Early Cretaceous sedimentary evolution of a pelagic basin margin (the Manín Unit, central Western Carpathians, Slovakia). Cretaceous Research 38, 68-79.

Nikolov, T. 1995. Lower Cretaceous. In: Yanev, S. (Ed), Explanatory note for the geological map of Bulgaria in scale 1:100 000, Sofia map sheet. Avers ST, Sofia, 62-63 (in Bulgarian).

Nikolov, T., Sapunov, I. 1970. On the regional stratigraphy of the Upper Jurassic and part of the Lower Cretaceous in Balkanides. Comptes rendus de l'Académie bulgare des Sciences 23 (11), 1397-1400 (in Russian).

Nikolov, T., Tzankov, Tz. 1998. The position of the Salash formation (Lower Cretaceous) near Dragoman village, Sofia district. Review of the Bulgarian Geological Society 59 (3), 119-123 (in Bulgarian, with English abstract).

Nikolov, T., Zankov, Z. 1971. Notes sur la lithostratigraphie d'une partie des sediments du Crétacé inférieur dans les Balkanides de l'ouest. Bulletin of the Geological Institute, Series Stratigraphy and Lithology 20, 63-70 (in Bulgarian, with Russian and French abstracts).

Ogg, J.G., Hinnov, L.A. 2012. Jurassic. In: Gradstein, F.M., Ogg, J.G., Schmitz, M.D., Ogg, G.M. (Eds), The Geological Time Scale. Elsevier, Oxford, 731-791.

Omaña, L., Alencaster, G., Buitrón, B.E. 2016. Mid-early late Albian foraminiferal assemblage from the El Abra Formation in the El Madroño locality, eastern Valles-San Luis Potosí Platform, Mexico: Paleoenvironmental and paleobiogeographical significance. Boletín de la Sociedad Geológica Mexicana 63 (3), 477-496.

Petrova, S., Lakova, I., Ivanova, D. 2010. The Salash Formation in Western Srednogorie: lithology, age and boundaries. Bulgarian Geological Society, National Conference with International Participation "Geosciences 2010", Abstracts, 93-94 (in Bulgarian).

Petrova, S., Lakova, I., Ivanova, D. 2011. Berriasian-Valanginian boundary in Bulgaria. Review of the Bulgarian Geological Society 72 (1-3), 91-97.
Petrova, S., Ivanova, D., Nikolov, N., Koleva-Rekalova, E., Lakova, I. 2014. Microfossil record and facies transitions of Oxfordian to Berriasian carbonates in the Western Srednogorie, Bulgaria. In: Beqiraj, A., Ionescu, C., Christofides, G., Uta, A., Beqiraj Goga, E., Marku, S. (Eds), Buletini $i$ Shkencave Gjeologjike, Proceedings of XX CBGA Congress, 24-26 September 2014, Tirana, Albania, Special Issue 2, 79-80.

Pop, G. 1994a. Systematic revision and biochonology of some Berriasian-Valanginian calpionellids (genus Remaniella). Geologica Carpathica 45 (6), 323-331.

Pop, G. 1994b. Calpionellid evolutive events and their use in biostratigraphy. Romanian Journal of Stratigraphy 76, 7-24.

Pop, G. 1996. Trois nouvelles espèces du genre Remaniella (Calpionellidae Bonet, 1956). Comptes rendus de l'Académie des Sciences de Paris, Série IIa 322, 317-323.

Pop, G. 1997a. Tithonian to Hauterivian praecalpionellids and calpionellids: bioevents and biozones. Mineralia Slovaca 29 (4-5), 304-305.

Pop, G. 1997b. Révision systématique des chitinoïdelles tithoniennes des Carpathes méridionales (Roumanie). Comptes rendus de l'Académie des Sciences de Paris, Série IIa 324, 931-938.

Pop, G. 1998. Nouvelles chitinoïdelles tithoniennes des Carpathes méridionales (Roumanie). Comptes rendus de l'Académie des Sciences de Paris, Série de la terre et des planètes 326, 817-822.

Rameil, N., Immenhauser, A., Warrlich, G., Hillgärtner, H., Droste, H.J. 2010. Morphological patterns of Aptian Lithocodium-Bacinella geobodies: relation to environment and scale. Sedimentology 57, 883-911.

Reháková, D. 1998. Calpionellid genus Remaniella Catalano 1956 in Lower Cretaceous pelagic deposits of western Carpathians. Mineralia Slovaca 30 (6), 443-452.

Reháková, D. 2002. Chitinoidella Trejo, 1975 in middle Tithonian carbonate pelagic sequences of the West Carpathian Tethyan area. Geologica Carpathica 53 (6), 369-379.

Reháková, D., Michalík, J. 1997. Evolution and distribution of calpionellids - the most characteristic constituents of Lower Cretaceous Tethyan microplankton. Cretaceous Research 18, 493-504.

Sallouhi, H., Boughdiri, M., Cordey, F. 2011. Tithonian Chitinoidellids of the South-Tethyan Margin of the Maghreb: new data from northern Tunisia. Comptes Rendus Palevol 10, 641-653.

Sapunov, I., Tchoumatchenco, P. 1995. Jurassic. In: Yanev, S. (Ed.), Explanatory note for the geological map of Bulgaria in scale 1:100 000, Sofia map sheet. Avers ST, Sofia, 5162 (in Bulgarian).

Sapunov, I., Tchoumatchenco, P., Dodekova, L., Bakalova, D. 1985. Stratigraphy of the Callovian and Upper Jurassic rocks in South-western Bulgaria. Geologica Balcanica 15 (2), 3-61 (in Russian, with English abstract). 